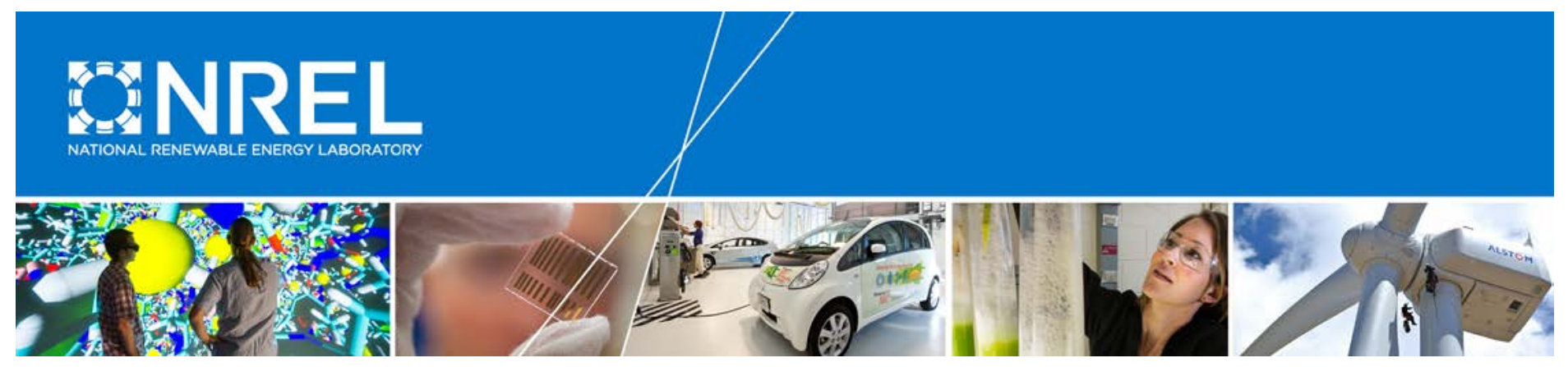

\title{
Bureau of Reclamation Hydropower Lease of Power Privilege: Case Studies and Considerations
}

Taylor Curtis, Aaron Levine, and Katie McLaughlin National Renewable Energy Laboratory

NREL is a national laboratory of the U.S. Department of Energy Office of Energy Efficiency \& Renewable Energy Operated by the Alliance for Sustainable Energy, LLC

This report is available at no cost from the National Renewable Energy Laboratory (NREL) at www.nrel.gov/publications.

Technical Report

NREL/TP-6A20-71092

May 2018 
Bureau of Reclamation Hydropower Lease of Power Privilege: Case Studies and Considerations

\author{
Taylor Curtis, Aaron Levine, \\ and Katie McLaughlin \\ National Renewable Energy Laboratory
}

\section{Suggested Citation}

Curtis, Taylor, Aaron Levine, and Katie McLaughlin. 2918. Bureau of Reclamation Hydropower Lease of Power Privilege: Case Studies and Considerations. Golden, CO: National Renewable Energy Laboratory. NREL/TP-6A20-71092. https://www.nrel.gov/docs/fy18osti/71092.pdf.

NREL is a national laboratory of the U.S. Department of Energy Office of Energy Efficiency \& Renewable Energy Operated by the Alliance for Sustainable Energy, LLC

This report is available at no cost from the National Renewable Energy Laboratory (NREL) at www.nrel.gov/publications.

\section{Technical Report}

NREL/TP-6A20-71092

May 2018

Contract No. DE-AC36-08GO28308
National Renewable Energy Laboratory 15013 Denver West Parkway

Golden, CO 80401

303-275-3000 • www.nrel.gov 


\section{NOTICE}

This report was prepared as an account of work sponsored by an agency of the United States government. Neither the United States government nor any agency thereof, nor any of their employees, makes any warranty, express or implied, or assumes any legal liability or responsibility for the accuracy, completeness, or usefulness of any information, apparatus, product, or process disclosed, or represents that its use would not infringe privately owned rights. Reference herein to any specific commercial product, process, or service by trade name, trademark, manufacturer, or otherwise does not necessarily constitute or imply its endorsement, recommendation, or favoring by the United States government or any agency thereof. The views and opinions of authors expressed herein do not necessarily state or reflect those of the United States government or any agency thereof.

This report is available at no cost from the National Renewable Energy Laboratory (NREL) at www.nrel.gov/publications.

Available electronically at SciTech Connect http:/www.osti.gov/scitech

Available for a processing fee to U.S. Department of Energy and its contractors, in paper, from:

U.S. Department of Energy

Office of Scientific and Technical Information

P.O. Box 62

Oak Ridge, TN 37831-0062

OSTI http://www.osti.gov

Phone: 865.576.8401

Fax: 865.576.5728

Email: reports@osti.gov

Available for sale to the public, in paper, from:

U.S. Department of Commerce

National Technical Information Service

5301 Shawnee Road

Alexandria, VA 22312

NTIS http://www.ntis.gov

Phone: 800.553 .6847 or 703.605 .6000

Fax: 703.605.6900

Email: orders@ntis.gov 


\section{Acknowledgments}

The authors gratefully acknowledge the U.S. Department of Energy Office of Energy Efficiency and Renewable Energy Water Power Technologies Office for its funding support. We also thank the following reviewers for their time and expertise: Corey Vezina and Tim Welch, U.S.

Department of Energy; Clark Bishop, U.S. Bureau of Reclamation; and Jaquelin Cochran, Dave Mooney, and Sheri Anstedt (editor), National Renewable Energy Laboratory.

We also thank the following contributors for their time and expertise: Catherine Cunningham, Luke Buchholz, and Ryan Christianson, U.S. Bureau of Reclamation; Carl Brouwer, Northern Colorado Water Conservancy District; Jim Heneghan, Delta-Montrose Electric Association; and Mike Berry and Kathleen Margetts, Tri-County Water Conservancy District. 


\section{Executive Summary}

In 2016, the hydropower fleet in the United States produced more than 6\% (approximately 265,829 gigawatt-hours) of total net electricity generation and $46 \%$ of electricity generation of all renewables. The United States has considerable hydroelectric potential beyond what is already being developed. The U.S. Department of Energy's Hydropower Vision study modeled a scenario identifying 49 gigawatts of deployable hydroelectric potential by 2050. Approximately 12 gigawatts of the potential identified is found by powering existing nonpowered dams and an additional 1-2 gigawatts of potential is found by installing hydropower at existing conduits.

The U.S. Department of Interior's Bureau of Reclamation (Reclamation) - the nation's second largest producer of hydroelectric power-has identified approximately 370 megawatts (MW) of hydroelectric potential at Reclamation-owned dams and conduits. Reclamation's hydroelectric potential coupled with recent federal initiatives encouraging development at federally owned facilities has led to an increased interest in powering Reclamation-owned nonpowered dams and conduits through a lease of power privilege (LOPP) contract. A LOPP is a contractual authorization by Reclamation to a nonfederal entity to use a Reclamation dam or conduit for electric power generation consistent with Reclamation project purposes.

During the last 5 years, 23 of the 36 total LOPP projects were initiated and are at some phase of the development process. As of December 2017, 13 LOPP projects with an installed capacity of nearly $46 \mathrm{MW}$ are online, while the remaining 23 LOPP projects with a total nameplate capacity of approximately $30 \mathrm{MW}$ have been initiated.

Reclamation's efforts to streamline the LOPP regulatory process, beginning in 2012, coupled with federal statutory changes in 2013 have led to decreased processing timelines. Prior to streamlining efforts, the timeline from the project initiation date to the LOPP contract date ranged from 9 months to 102 months, while the mean and median timelines for these projects were approximately 42.5 months and 31 months, respectively. Post streamlining efforts, the timeline from the project initiation date to the LOPP contract date ranged between 6.5 months and 13 months, while the mean and median timelines for these projects was approximately 9.5 months and 10 months, respectively. 


\section{Table of Contents}

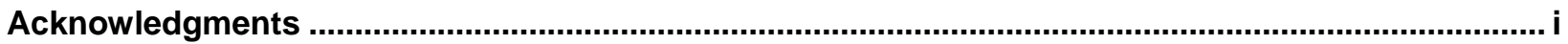

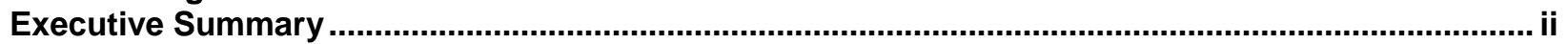

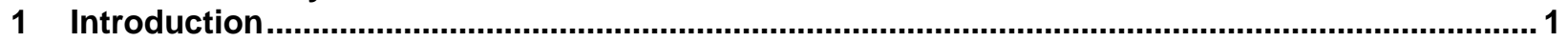

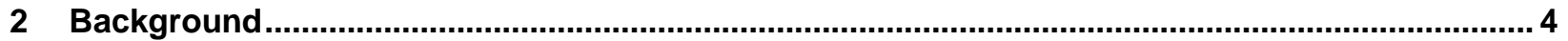

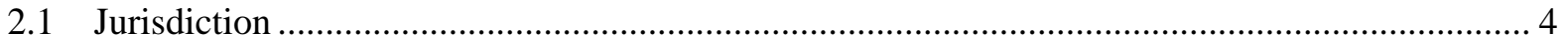

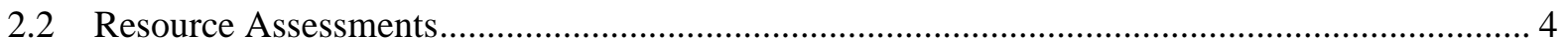

2.3 Lease of Power Privilege Contracts and Projects Online ........................................................ 6

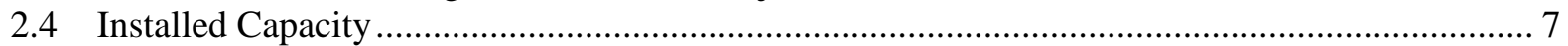

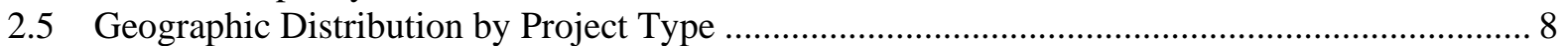

2.6 Bureau of Reclamation Small Conduit Hydropower Development and Rural Jobs Act............... 8

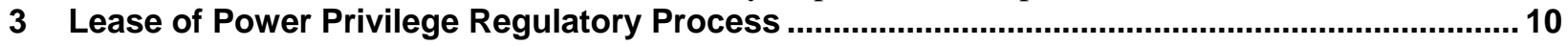

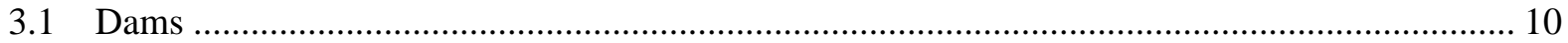

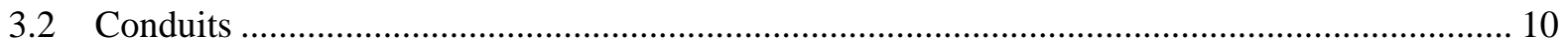

3.3 Competitive Solicitation Process vs. Right-of-First Refusal Usage ......................................... 12

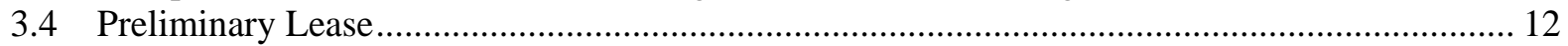

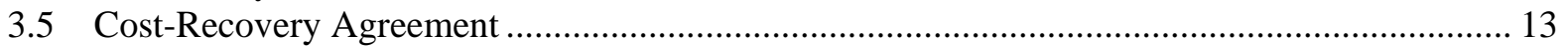

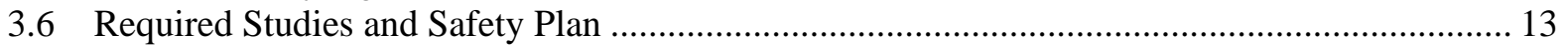

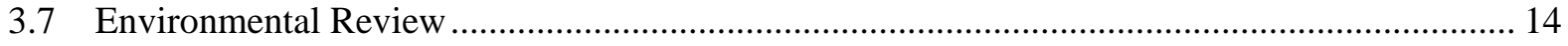

3.8 Execution of the Lease of Power Privilege ............................................................................. 16

$4 \quad$ Lease of Power Privilege Case Studies and Timelines ............................................................. 18

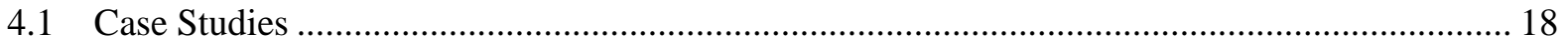

4.2 Lease of Power Privilege Process Timelines ............................................................................. 25

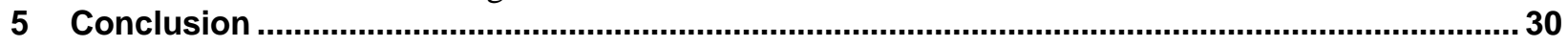

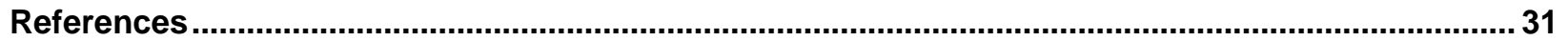

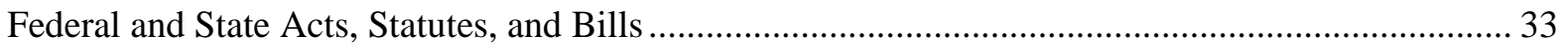

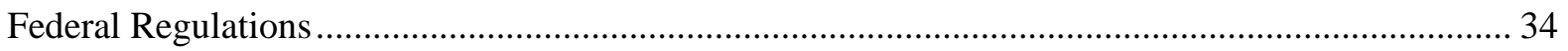

Appendix A. Lease of Power Privilege Projects for Timeline Analysis ...................................... 35

\section{List of Figures}

Figure 1. Reclamation 2012 conduit hydropower resource assessment - potential by state ............ 6

Figure 2. Lease of power privilege projects - online date by year ................................................... 7

Figure 3. Lease of power privilege projects - installed capacity by year .......................................... 7

Figure 4. Lease of power privilege projects - geographic distribution .............................................. 8

Figure 5. Lease of power privilege conduit projects - initiated before and after 2013 Reclamation

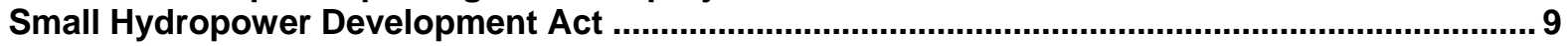

Figure 6. Lease of power privilege projects - right-of-first refusal versus competitive solicitation 12

Figure 7. Lease of power privilege projects - type of NEPA compliance document.........................15

Figure 8. South Canal Drop 3 Hydroelectric Project - 3.5 MW. Photo courtesy of DMEA ................. 18

Figure 9. Granby Dam Hydroelectric Project - 1.2 MW. Photo courtesy of NWCD...........................22

Figure 10. Lease of power privilege projects - timelines from initiation date to contract date ....... 26

Figure 11. Lease of power privilege projects - average timelines from initiation date to contract

date

Figure 12. Lease of power privilege projects - timelines from initiation date to contract date ....... 28

Figure 13. Lease of power privilege projects - average timelines from initiation date to online date 


\section{Introduction}

In 2016, the hydropower fleet in the United States produced more than 6\% (approximately 265,829 gigawatt-hours [GWh]) of total net electricity generation and $46 \%$ of electricity generation of all renewables (Martinez et al. 2017). The U.S. Department of Interior's Bureau of Reclamation (Reclamation) is the nation's second largest producer of hydroelectric power (Reclamation 2018f). Reclamation owns 76 hydropower facilities in the western United States with a total installed capacity of 15,520 megawatts (MW) (Reclamation 2017b).

Reclamation operates and maintains 53 reserved $^{1}$ hydropower facilities, comprising 14,730 MW of installed capacity (Reclamation 2018f). On average, these 53 facilities generate 40 million megawatt-hours (MWh) of electricity each year-the equivalent demand of over 3.5 million U.S. homes (Reclamation 2018f). Reclamation also owns an additional 23 transferred hydropower facilities, ${ }^{2}$ comprising $790 \mathrm{MW}$ of installed capacity, operated and maintained by a nonfederal entity in accordance with a formal operation and maintenance transfer contract (Reclamation 2018f).

In addition to the 76 federally owned hydropower facilities, 64 nonfederal hydropower facilities operate on Reclamation dams and conduits under the provisions of either a Federal Energy Regulatory Commission (FERC) license or exemption (51 facilities with a total installed capacity of $466 \mathrm{MW}$ ) or a lease of power privilege (LOPP) contract (13 facilities with a total installed capacity of nearly $46 \mathrm{MW}$ ) (Reclamation 2018f). A LOPP is a contractual authorization issued by Reclamation to a nonfederal entity to use a Reclamation dam or conduit ${ }^{3}$ for electric power generation consistent with Reclamation project purposes (Reclamation 2014b).

Recent federal initiatives encouraging hydropower development at federally owned facilities coupled with Reclamation's hydroelectric potential has led to an increased interest in powering Reclamation dams and conduits through the LOPP process. During the last 5 years, 23 of the 36 total LOPP projects were initiated ${ }^{4}$ and are at some phase of the development process (Reclamation 2017a).

The U.S. Department of Energy's (DOE’s) Hydropower Vision study modeled a scenario identifying 49 gigawatts (GW) of deployable hydroelectric potential by 2050 (DOE 2016). Approximately $12 \mathrm{GW}$ of the potential identified is found by powering existing nonpowered dams and an additional 1-2 GW of potential is found by installing hydropower at existing conduits (DOE 2016; Sale 2014). Resource assessments conducted in furtherance of a 2010

\footnotetext{
${ }^{1}$ A "reserved hydropower facility" is a hydropower facility owned and operated by Reclamation (Reclamation 2018a).

${ }^{2}$ A "transferred hydropower facility" is a hydropower facility owned by Reclamation but operated and maintained by a nonfederal entity in accordance with a formal operation and maintenance transfer contact (Reclamation 2018f).

${ }^{3}$ A "conduit" is defined as "any tunnel, canal, pipeline, aqueduct, flume, ditch, or similar manmade water conveyance that is operated for the distribution of water for agricultural, municipal, or industrial consumption and not primarily for the generation of electricity or conveyance of water over or through a dam, its abutments, or foundation via existing or proposed conveyance features" (Reclamation 2014b).

4 "Initiated" in this context refers to the initiation date of a LOPP project. The "initiation date" for the purposes of this report refers to either the date that Reclamation posts notice in the Federal Register requesting proposals for hydropower development as part of the competitive solicitation process or the date Reclamation receives a formal request for development from an irrigation district or water users association exercising its right-of-first refusal to develop hydropower at a Reclamation conduit (Reclamation 2017a).
} 
interagency partnership between the U.S. Department of Interior, DOE, and the U.S. Department of Army to encourage small hydropower development identified approximately $370 \mathrm{MW}$ of potential at Reclamation dams and conduits (Hadjerioua et al. 2012; Reclamation 2012d; Reclamation 2011b).

To encourage the development of the hydropower potential identified, Congress passed the Bureau of Reclamation Small Conduit Hydropower Development and Rural Jobs Act of 2013 (Reclamation Small Hydropower Development Act), which amended the Reclamation Project Act of 1939 to authorize the development of small conduit hydropower projects (5 MW or less) on Reclamation-owned conduits exclusively through the LOPP process. The Reclamation Small Hydropower Development Act also:

- Directed Reclamation to apply its categorical exclusion process under the National Environmental Policy Act to small conduit hydropower activities

- Amended Reclamation's LOPP process for conduit development to give priority rights to irrigation districts and water users associations operating or receiving water from the Reclamation-owned conduit.

Reclamation has also made efforts to simplify the LOPP regulatory process to encourage nonfederal hydropower development on Reclamation-owned dams and conduits. In September 2012, Reclamation worked with industry and other stakeholders to issue a streamlined LOPP process, defined in the Reclamation Manual Directive and Standard, Lease of Power Privilege Processes, Responsibilities, Timelines, and Charges. ${ }^{5}$ Reclamation has continuously updated the LOPP Directive and Standard over the years to increase transparency and efficiency and ensure consistent LOPP program administration and communication (Reclamation 2014b).

Reclamation's effort to streamline the LOPP regulatory process coupled with federal statutory changes in 2013 have led to decreased processing timelines. Prior to streamlining efforts, the timeline from the project initiation date ${ }^{6}$ to the LOPP contract date ranged from 9 months to 102 months, while the mean and median timelines for these projects were approximately 42.5 months and 31 months, respectively. Post streamlining efforts, the timeline from the project initiation date to the LOPP contract date ranged between 6.5 months and 13 months, while the mean and median timelines for these projects was approximately 9.5 months and 10 months, respectively. ${ }^{7}$ As of December 2017, 13 LOPP projects with an installed capacity of nearly 46 MW are online, while the remaining 23 LOPP projects with a total nameplate capacity of approximately $30 \mathrm{MW}$ have been initiated (Reclamation 2017a).

This report analyzes the Reclamation LOPP regulatory process for a nonfederal entity to use a Reclamation dam or conduit for power generation. This report also provides considerations from

\footnotetext{
${ }^{5}$ The Reclamation Manual Directives and Standard, Lease of Power Privilege Processes, Responsibilities, Timelines, and Charges (FAC 04-08) establishes the process requirements and charges associated with the nonfederal development of hydropower at Reclamation dams and conduits and Water Conservation and Utilization Act projects authorized through a LOPP (Reclamation 2014b).

${ }^{6}$ The "initiation date" for the purposes of this report refers to either the date that Reclamation posts notice in the Federal Register requesting proposals for hydropower developed as part of the competitive solicitation process or the date Reclamation receives a formal request for development from an irrigation district or water users association exercising its right-of-first refusal to develop hydropower at a Reclamation conduit (Reclamation 2017a).

${ }^{7}$ All of these initiated projects, post streamlining efforts, are sited on Reclamation conduits.
} 
Reclamation staff involved in the LOPP regulatory process and developers that have a LOPP and are currently generating hydropower at a Reclamation-owned dam or conduit.

Section 2 provides background information on Reclamation's jurisdiction over hydropower projects, Reclamation resource assessments, and a summary of active LOPP projects.

Section 3 discusses the LOPP regulatory process for a nonfederal entity to develop a hydropower project on a Reclamation-owned dam or conduit and provides considerations from Reclamation staff concerning the process.

Section 4 provides LOPP regulatory process timelines and case studies of hydropower projects that have obtained a LOPP and are currently generating electricity at a Reclamation-owned dam or conduit.

Section 5 provides current trends regarding LOPP projects in the western United States. 


\section{Background}

A LOPP grants a contractual right, of 40 years or less, to a nonfederal entity to use a Reclamation dam or conduit for electric power generation consistent with Reclamation project purposes (Reclamation 2014b). This section discusses the Reclamation Small Hydropower Development Act of 2013 and its impact on the LOPP process, statistics regarding current LOPP hydropower projects, the hydropower potential at Reclamation-owned dams and conduits, and the jurisdictional boundaries of Reclamation and FERC regarding nonfederal hydropower development at Reclamation-owned dams and conduits.

\subsection{Jurisdiction}

Both Reclamation and FERC are authorized to approve the use of a Reclamation dam or conduit for nonfederal hydropower development. A nonfederal entity (herein developer) must obtain either a Reclamation LOPP or a FERC license or exemption, but not both, to use a Reclamation asset (i.e., dam or conduit) for hydropower development (FERC 1992). Requests to develop hydropower at Reclamation assets are evaluated under the 1992 memorandum of understanding between FERC and Reclamation ${ }^{8}$ to determine which agency has jurisdiction over the proposed project (Reclamation 2014b; FERC 1992).

Reclamation has exclusive authority to authorize the use of all Reclamation conduits and water resource assets (e.g., dams, conduits, and reservoirs) constructed pursuant to the Water Conservation and Utilization Act of $1939^{9}$ (Reclamation Project Act of 1939; Carl Levin and Howard P. "Buck” McKeon National Defense Authorization Act for Fiscal Year 2015). Reclamation also has jurisdiction over Reclamation dams authorized for federal hydropower development (FERC 1992). FERC has the authority to grant a hydropower license or exemption to a developer on those Reclamation assets not under the exclusive jurisdiction of Reclamation (i.e., Reclamation dams not authorized for federal hydropower development) (FERC 1992). A nonfederal hydropower project that requires the use of multiple federal assets may require both a LOPP and a FERC authorization, ${ }^{10}$ wherein one asset is within Reclamation's jurisdiction and the second asset is within FERC's jurisdiction (Reclamation 2018a).

\subsection{Resource Assessments}

In March 2010, the U.S. Department of Interior, DOE, and the U.S. Department of Army through the U.S. Army Corps of Engineers entered into a memorandum of understanding (2010 MOU) to coordinate, in part, their efforts to advance low-impact, small hydropower development at federally owned facilities (DOE 2010; DOE 2015). One of the 2010 MOU initiatives included an action to conduct federal facility energy resource assessments. In coordination with interagency partners, Reclamation conducted two studies assessing hydroelectric potential at existing Reclamation dams and conduits. The Oak Ridge National Laboratory also conducted a study for

\footnotetext{
${ }^{8}$ Memorandum of Understanding Between the Federal Energy Regulatory Commission, and the Department of Interior, Bureau of Reclamation for Establishment of Processes for Early Resolution of Issues Related to the Timely Development of Non-Federal Hydroelectric Power at Bureau of Reclamation Facilities. 58 Fed. Reg. 3269 (Nov. 6, 1992).

${ }^{9}$ Water Conservation and Utilization Act of 1939, PL 398-76, 53 Stat. 1418 (Aug. 11, 1939) (authorizes the U.S. Department of Interior to construct water conservation and utilization projects in the Great Plains and arid and semiarid areas of the United States).

${ }^{10}$ An "authorization" includes both FERC licenses and FERC exemptions from licensing.
} 
DOE identifying hydroelectric potential at existing dams that included an assessment of Reclamation dams (Hadjerioua et al. 2012). The Oak Ridge National Laboratory resource assessment found approximately $260 \mathrm{MW}$ of hydroelectric potential at Reclamation-owned dams (Hadjerioua et al. 2012).

A 2011 Reclamation resource assessment reviewed 530 identified sites (i.e., reservoir dams, diversion dams, canals, tunnels, dikes, and siphons) previously identified in a 2007 study ${ }^{11}$ and assessed the hydropower potential at those sites regardless of size (Reclamation 2011b). The 530 sites identified span Reclamation's five regions, compromised of 17 western states (Reclamation 2011b). Of the 530 identified sites, the study found that 191 of those sites (dams and conduits) had some level of hydropower potential (Reclamation 2011b). If developed, the 191 sites had a total capacity of approximately 268 MW (Reclamation 2011b). Further analysis found that 70 of those 191 sites had potential for cost-productive hydropower development. ${ }^{12}$ The development of many of these sites would occur under a LOPP rather than a FERC license (Reclamation 2011b).

Because the 2011 resource assessment scope was limited to 2007 study sites that did not comprehensively assess hydropower potential at Reclamation-owned conduits, Reclamation conducted a supplemental conduit resource assessment in 2012. ${ }^{13}$ The 2012 resource assessment identified 373 Reclamation conduit sites with approximately 104 MW of hydropower potential in 13 of the 17 westerns states. Figure 1 illustrates that approximately $70 \%$ of the capacity and energy potential on Reclamation-owned conduits is located in Colorado, Wyoming, and Oregon (Reclamation 2012d). In accordance with the Bureau of Reclamation Small Hydropower Development Act of 2013, all hydropower potential developed on Reclamation conduits would occur under a LOPP.

\footnotetext{
11 The 2007 study, entitled, “Potential Hydropower Development at Existing Federal Facilities,” was completed pursuant to section 1834 of the Energy Policy Act of 2005. The study did not include many small- and low-head sites (Reclamation 2012d). 12 Reclamation's cost-productive analysis was based on cost-benefit ratio assessments that took into account regulatory and environmental constraints related to the water supply at each site, as well as green incentives that may benefit the site, the proximity to transmission infrastructure, and other factors (Reclamation 2011b).

13 The 2011 Reclamation resource assessment did not evaluate new sites and relied on the canals identified from the 2007 study, which did not identify specific drops in the canals, and only listed the head differential along the entire stretch of the canals (Reclamation 2012d).
} 


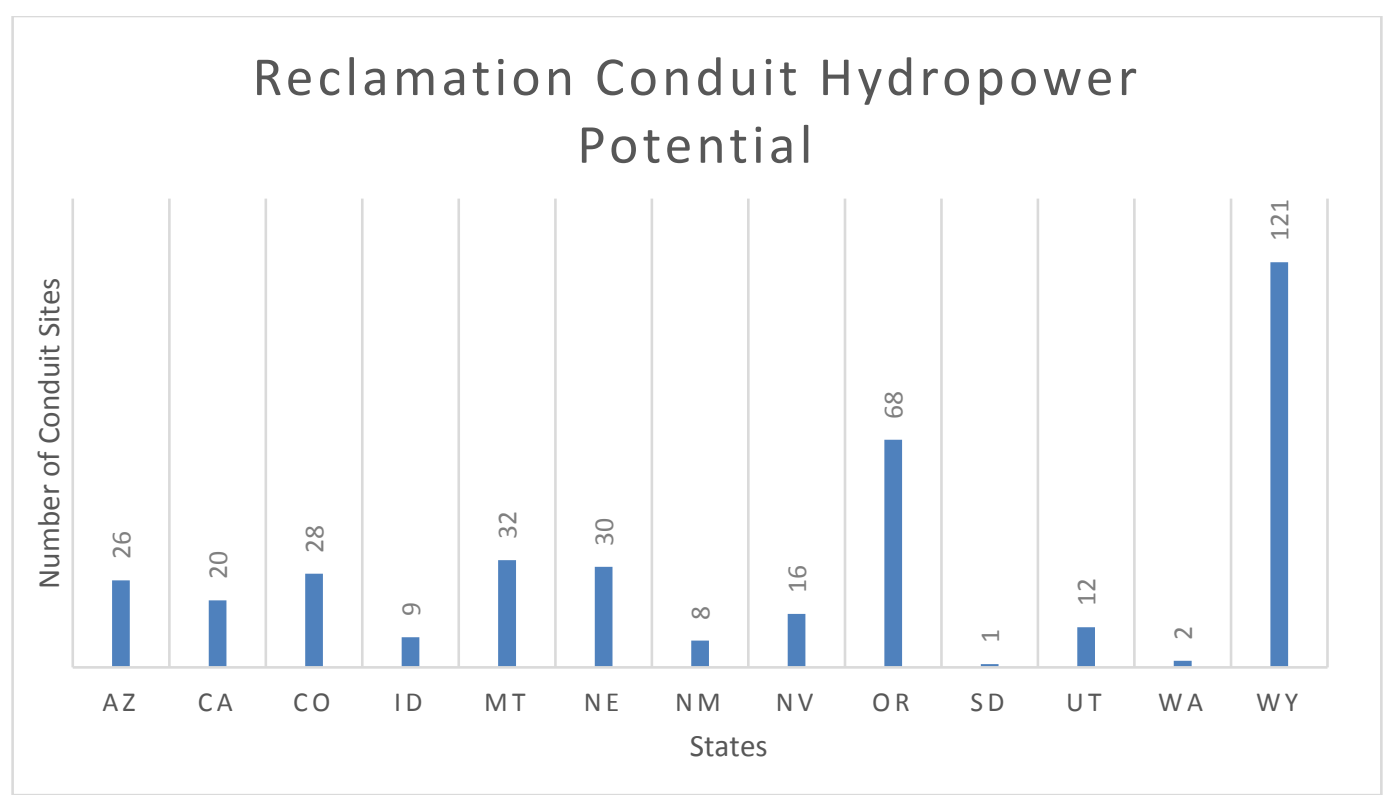

Figure 1. Reclamation 2012 conduit hydropower resource assessment - potential by state

\subsection{Lease of Power Privilege Contracts and Projects Online}

As of December 2017, there are a total of 36 active LOPP projects. ${ }^{14}$ Of the 36 projects, Reclamation has issued a LOPP contract to 16 projects and 13 of those projects are online with a total installed capacity of 45.6 MW (Reclamation 2017a). ${ }^{15}$ Six of the thirteen projects online are at Reclamation conduits and the remaining seven are at Reclamation dams (Reclamation 2017a). Of the total online projects, nine came online between 2012 and 2016, averaging two projects a year (Reclamation 2017a). Four projects came online prior to 2012 in 1938, 1988, 1995, and 2008 (Reclamation 2017a). Six of the projects online were identified as sites with hydropower potential in either the 2011 or 2012 Reclamation resource assessment (Reclamation 2017a). Figure 2 illustrates the number of LOPP projects that have come online by year.

\footnotetext{
14 Total active LOPP projects include those that have received a LOPP and that are online and those that have been identified and are at some stage of the LOPP process (e.g., request for development, drafting public solicitation, preliminary lease, LOPP contract). An additional three canal projects in Montana have been identified but are currently inactive.

${ }^{15}$ Reclamation authorized the use of Canal Drop 1 and Canal Drop 3 through a single LOPP contract.
} 


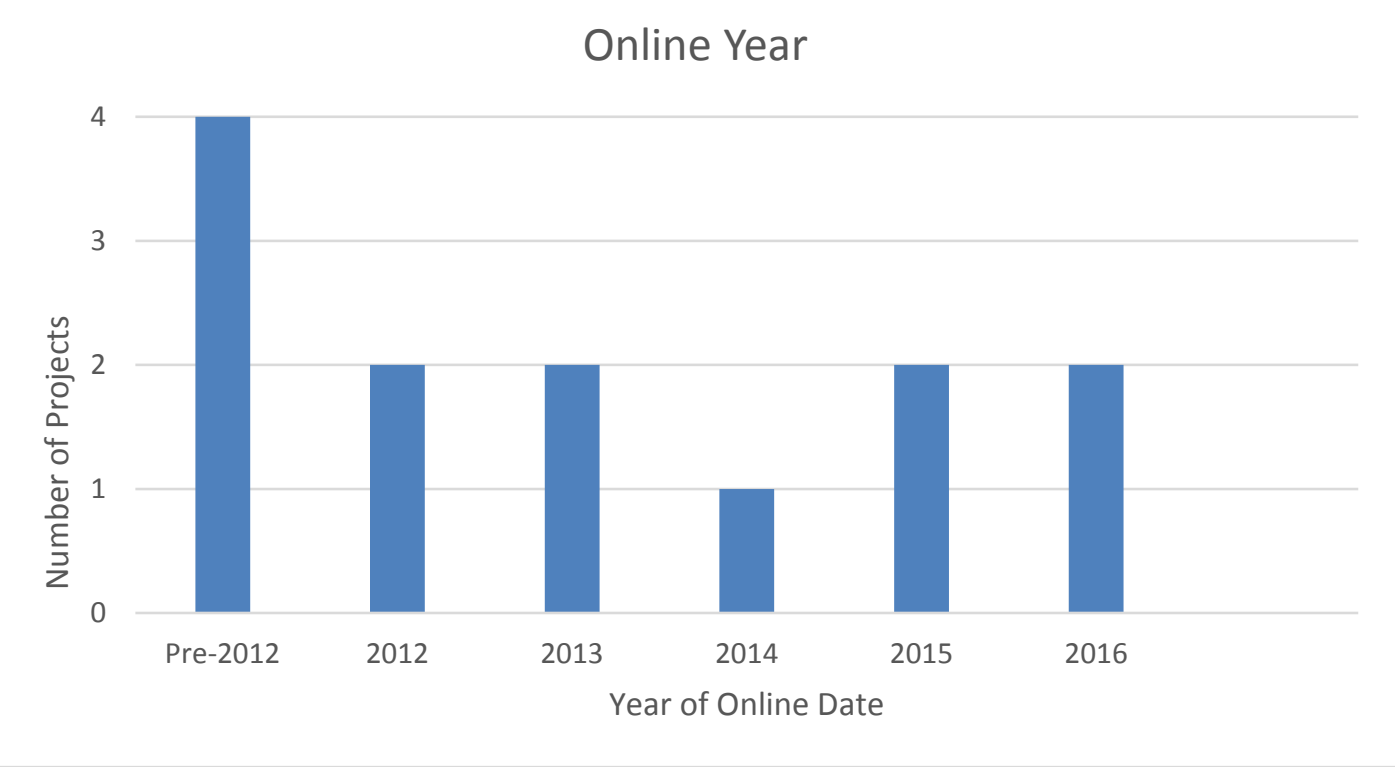

Figure 2. Lease of power privilege projects - online date by year

\subsection{Installed Capacity}

Figure 3 illustrates the range of installed capacity for the LOPP projects online distributed by year. Installed capacity for the 13 projects varied between 120 kilowatts (kW) and 13 MW. Most of the projects have an installed capacity of less than $5 \mathrm{MW}$. The largest LOPP project to date is the Jordanelle Dam Hydropower Project, with an installed capacity of 13 MW (Reclamation 2017a). In addition, of the 36 active LOPP projects, 23 are currently in the development process, but not yet online (e.g., drafting public solicitation, request for development, posted solicitation, preliminary lease, LOPP contract but not constructed). These 23 projects have a total nameplate capacity of approximately 30 MW (Reclamation 2017a).

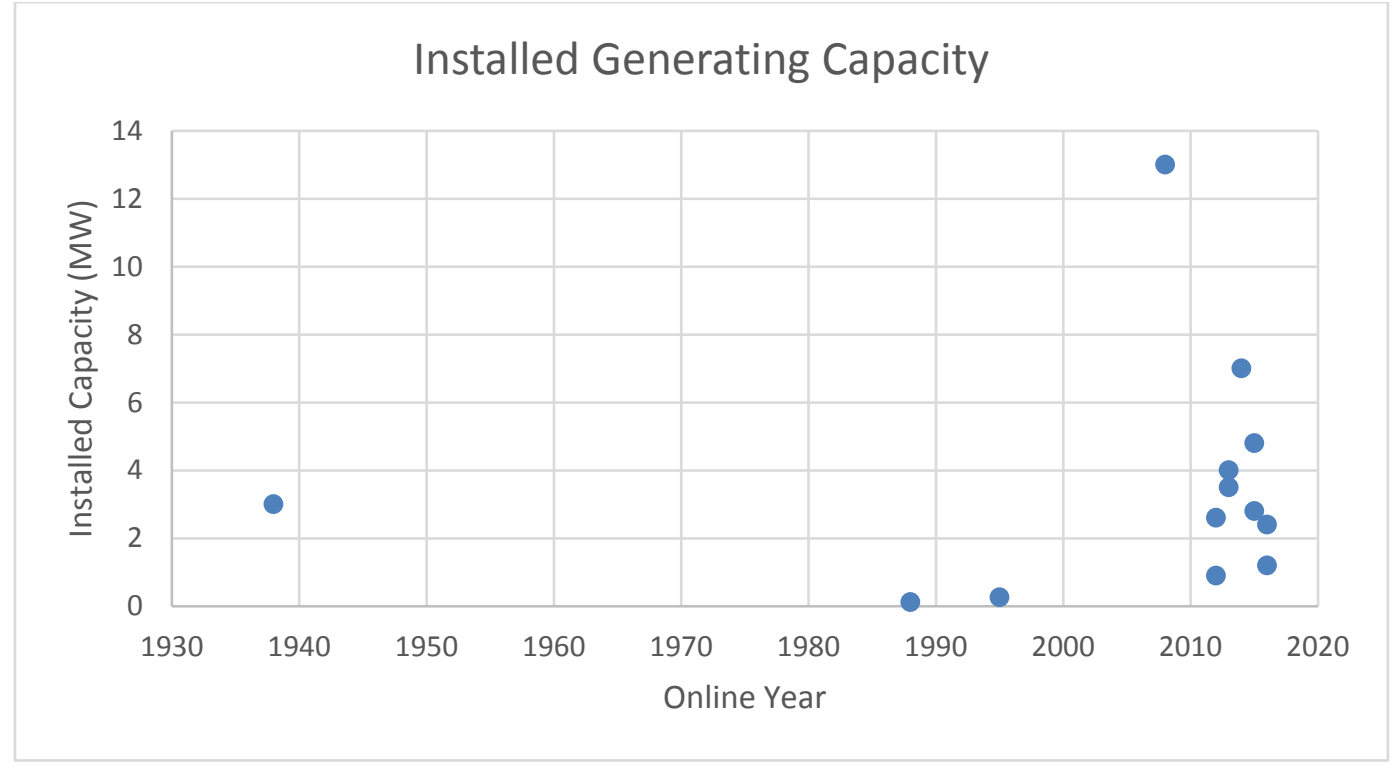

Figure 3. Lease of power privilege projects - installed capacity by year 


\subsection{Geographic Distribution by Project Type}

Figure 4 illustrates the geographic distribution of all 36 active LOPP projects, ${ }^{16}$ including those that are not yet online. Overall, the majority of LOPP projects are in Colorado and Oregon. In Colorado, there are 9 active LOPP dam projects and 7 conduit projects (Reclamation 2017a). In Oregon, there are no dam projects and 13 active LOPP conduit projects (Reclamation 2017a).

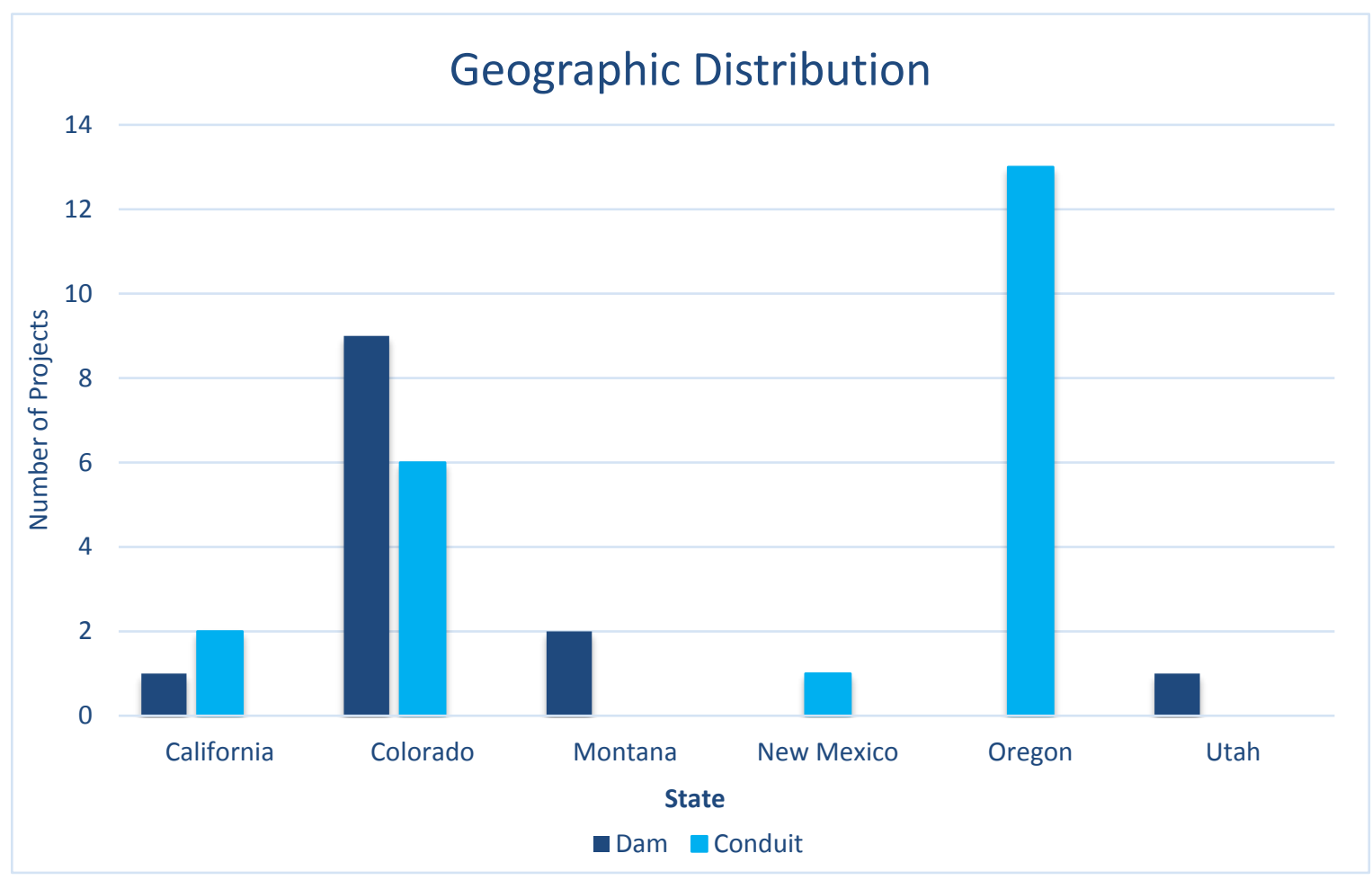

Figure 4. Lease of power privilege projects - geographic distribution

\subsection{Bureau of Reclamation Small Conduit Hydropower Development and Rural Jobs Act}

The Reclamation Small Hydropower Development Act of 2013 modified the LOPP process for hydropower development. The Reclamation Small Hydropower Development Act of 2013 amended the Reclamation Project Act of 1939 to:

1. Authorize nonfederal development of small conduit hydropower projects (5 MW or less) on Reclamation-owned infrastructure via a LOPP

\footnotetext{
${ }^{16}$ Active LOPP projects include those that have received a LOPP and that are online and those that have been identified and are at some stage of the LOPP process (e.g., request for development, drafting public solicitation, preliminary lease, LOPP contract). An additional three canal projects in Montana have been identified but are currently inactive.
} 
2. Require Reclamation to offer LOPPs first to an irrigation district ${ }^{17}$ or water users association ${ }^{18}$ operating or receiving water from the applicable transferred conduit or reserved conduit

3. Require Reclamation to offer the LOPP to other parties if the irrigation district or water users association elects not to accept the LOPP offer

4. Require Reclamation to apply its categorical exclusion process under the National Environmental Policy Act of 1969 to small conduit hydropower development (Bureau of Reclamation Small Conduit Hydropower Development and Rural Jobs Act 2013).

Figure 5 illustrates the number of conduit LOPP projects initiated by year. Of the total 36 active LOPP projects, 13 are at Reclamation dams and the remaining 23 are at Reclamation conduits. Of the 23 active Reclamation conduit projects, 19 of those projects were initiated ${ }^{19}$ after Congress enacted the Reclamation Small Hydropower Development Act (August 9, 2013).

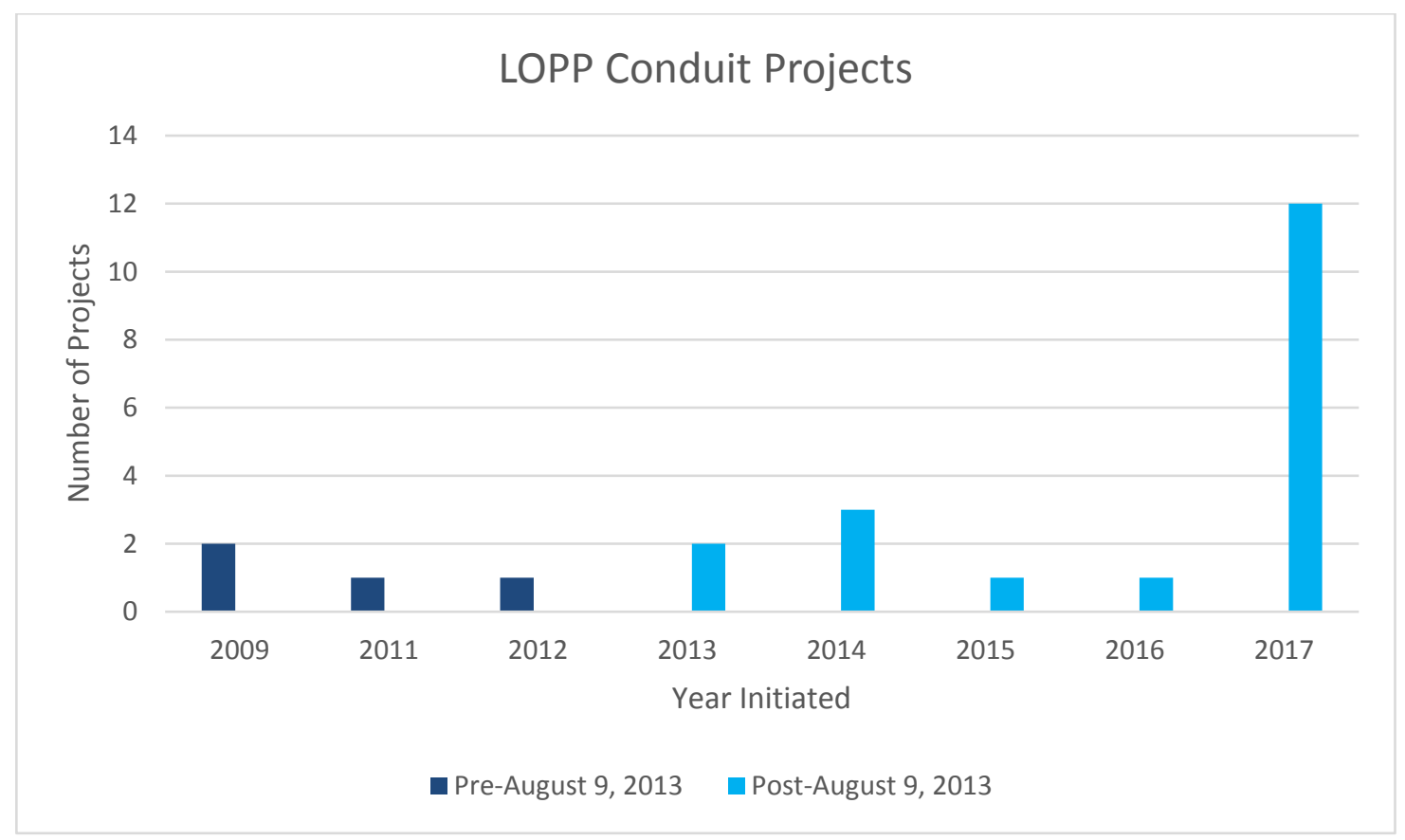

Figure 5. Lease of power privilege conduit projects - initiated before and after 2013 Reclamation Small Hydropower Development Act

\footnotetext{
${ }^{17}$ An "irrigation district" is any irrigation, water conservation or conservancy, multicounty water conservation or conservancy district, or any separate public entity composed of two or more such districts and jointly exercising powers to its member districts (Reclamation 2014b).

${ }^{18}$ A "water users association" is an organization that has a contract with Reclamation for the use or delivery of Reclamation project water (Reclamation 2014b).

19 The "initiation date" for the purposes of this report refers to either the date that Reclamation posts notice in the Federal Register requesting proposals for hydropower development as part of the competitive solicitation process or the date Reclamation receives a formal request for development from an irrigation district or water users association exercising its right-of-first refusal to develop hydropower at a Reclamation conduit (Reclamation 2017a).
} 


\section{Lease of Power Privilege Regulatory Process}

The regulatory process to obtain a LOPP depends on whether the project uses a Reclamation dam or a Reclamation conduit. Generally, the LOPP process for hydropower development on Reclamation dams follows a competitive public solicitation process. In contrast, the LOPP process for hydropower development on Reclamation conduits includes a right-of-first refusal, under which Reclamation must first offer the LOPP to any irrigation district or water users association operating or receiving water from the conduit (Reclamation 2014b). This section outlines some of the key steps in the LOPP regulatory process. ${ }^{20}$

\subsection{Dams}

To begin the LOPP process for hydropower development on a Reclamation dam, a developer may submit a Formal Request for Development (FRD) ${ }^{21}$ to the Reclamation regional director with jurisdiction or a Notice of Intent (NOI) to FERC. Once the FRD or a NOI is received, FERC and Reclamation coordinate to determine the appropriate permitting authority ${ }^{22}$ and notify the developer accordingly (Reclamation 2018a). Reclamation may also independently initiate the competitive solicitation process (CSP) for hydropower development on Reclamation dams (Reclamation 2014b). Prior to initiating the CSP for a dam project that is larger than $1 \mathrm{MW}$ and within Reclamation's jurisdiction, Reclamation must collaborate with relevant power marketing administrations and power and water stakeholders to determine whether there is an adequate interest in funding federal hydropower development at the proposed dam (Reclamation 2014b).

\subsubsection{Competitive Solicitation Process}

Reclamation solicits proposals for hydropower development on Reclamation dams through a public process to ensure fair and open competition. The LOPP solicitation includes evaluation criteria by which Reclamation selects a proposal. The CSP for LOPP proposals allows up to 150 days from the date of publication for developers to submit proposals. The Reclamation selection team then reviews all submitted proposals within 30 days and provides a recommendation to the Reclamation regional director to award a preliminary lease to the selected developer. Under the CSP, Reclamation must give priority to preference entities ${ }^{23}$ provided the entity is well-qualified to develop and provide for long-term operation and maintenance of the hydropower facility (Reclamation 2014b).

\subsection{Conduits}

To begin the LOPP process for hydropower development on a Reclamation conduit, a developer may submit an FRD to the Reclamation regional director with jurisdiction or a NOI to FERC. Reclamation conduits are under the exclusive jurisdiction of Reclamation and are either

\footnotetext{
${ }^{20}$ This section does not include every step in the LOPP regulatory process. All LOPP timeframes noted in this report may be adjusted by the Reclamation regional director for just cause.

${ }^{21}$ A "Formal Request for Development" is "an official letter to the regional director from a potential nonfederal developer requesting that the LOPP process be initiated at a Reclamation dam or conduit site or sites (Reclamation 2014b).

${ }^{22}$ In the event Reclamation and FERC cannot come to an agreement on the appropriate permitting authority, FERC's determination is final (FERC 1992).

${ }^{23}$ A "preference entity" includes municipalities, public agencies, public corporations, tribes, cooperatives, and nonprofit organizations financed in whole or in part by loans made pursuant to the Rural Electrification Act of 1936 (Reclamation 2014b).
} 
considered transferred work conduits ${ }^{24}$ or reserved work conduits. ${ }^{25}$ If the proposed conduit project is more than $1 \mathrm{MW}$, Reclamation must collaborate with the relevant power marketing administrations and power and water stakeholders to determine whether there is an adequate interest in funding federal hydropower development at the conduit (Reclamation 2014b).

\subsubsection{Right-of-First Refusal Process}

Upon receipt of an FRD, Reclamation must first offer the LOPP to the irrigation district or water users association operating or receiving water from the applicable conduit (Reclamation 2014; Bureau of Reclamation Small Conduit Hydropower Development and Rural Jobs Act 2013). ${ }^{26}$ Following the offer, the irrigation district or water users association has 60 days to either accept or reject, in writing, the opportunity to develop hydropower through a LOPP. If the irrigation district or water users association accepts the offer or if they initially submitted the FRD, then they have 150 days to submit a proposal to Reclamation. During this time, Reclamation does not solicit proposals from other entities and no other entity is eligible to receive a LOPP for the project site.

If the irrigation district or water users association rejects the opportunity to develop hydropower through a LOPP or fails to submit an acceptable proposal within 150 days, Reclamation will solicit proposals through the CSP, as described in Section 3.1.1. (Reclamation 2014; Bureau of Reclamation Small Conduit Hydropower Development and Rural Jobs Act 2013).

A Reclamation selection team reviews all submitted proposals and provides a recommendation to the Reclamation regional director to award a preliminary lease to the selected developer (Reclamation 2014b). The selection process for transferred conduits is slightly different from the selection process for reserved conduits. For development at transferred conduits, the Reclamation selection team has 14 days to review LOPP proposals and make a recommendation to the regional director to award a preliminary lease. For development at reserved conduits, the review period for the selection depends on how many, if any, irrigation districts or water users associations express interest in the LOPP (Reclamation 2014b). If a single irrigation district or water users association receiving water from the project submits a LOPP proposal, the Reclamation selection team has 14 days to review the LOPP proposal and make a recommendation to the regional director. If multiple irrigation districts or water users associations receiving water from the project submit LOPP proposals, the Reclamation selection team has 30 days to review the LOPP proposal and make a recommendation (Reclamation 2014b).

\footnotetext{
${ }^{24}$ A "transferred work conduit" is a Reclamation facility in which the operation and maintenance of the facility is carried out by a nonfederal entity under the provisions of a formal operation and maintenance transfer contract (Reclamation 2014b).

${ }^{25}$ A "reserved work conduit" is a facility owned by Reclamation, wherein Reclamation has retained responsibility for carrying out operation and maintenance activities (Reclamation 2014b).

${ }^{26}$ This includes both transferred work conduits and reserved work conduits.
} 


\subsection{Competitive Solicitation Process vs. Right-of-First Refusal Usage}

As of December 2017, 23 of the 36 total active LOPP hydropower projects ${ }^{27}$ are conduits. Four of those conduit projects have a project initiation date that predates the enactment of the Reclamation Small Hydropower Development Act of 2013 (August 9, 2013) and 19 of those projects have initiation dates after August 9, 2013. The four LOPP projects initiated before the Reclamation Small Hydropower Development Act of 2013 went through the CSP. For the 19 conduit projects initiated after August 9, 2013, Reclamation first offered the LOPP to the irrigation district or water users association operating or receiving water from the applicable conduit. Four irrigation districts or water users associations operate or receive water from the 19 conduit projects. Three of these irrigation districts or water users associations have exercised their right-of-first refusal over 7 of the conduit projects, while one irrigation district waived its right over the remaining 12 projects. After the irrigation district declined its right-of-first-refusal, these 12 projects began the CSP (Reclamation 2017a). Figure 6 illustrates the number of LOPP projects that have utilized the CSP and those that have been eligible for and utilized the right-offirst refusal process.

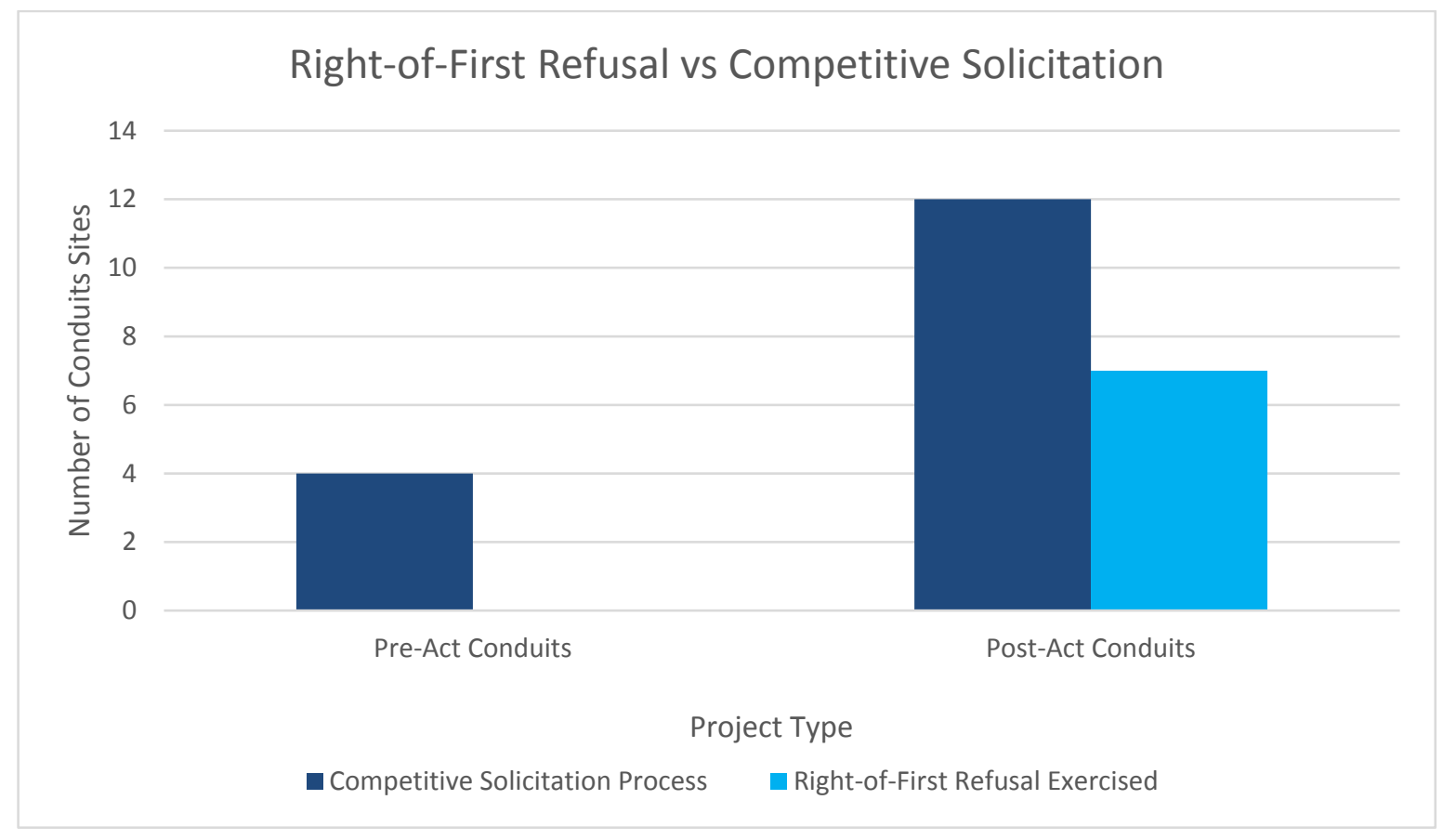

Figure 6. Lease of power privilege projects - right-of-first refusal versus competitive solicitation

\subsection{Preliminary Lease}

A preliminary lease is an agreement between Reclamation and the lessee that outlines the responsibilities of Reclamation and the lessee during the negotiation of the LOPP (Reclamation

\footnotetext{
${ }^{27}$ The total active LOPP hydropower projects include project sites identified for hydropower development at all stages of the LOPP process (e.g., drafting public solicitation, request for development, preliminary lease), LOPP-executed projects not yet constructed and/or online, and those projects with LOPPs that have executed LOPPs and are online and generating electricity (Reclamation 2017a).
} 
2014b). ${ }^{28}$ The selected preliminary lessee for a dam or a conduit has 24 and 15 months, respectively, from the date of the selection to sign the preliminary lease, complete the requirements set forth in the preliminary lease, and sign the LOPP (Reclamation 2014b).

\subsubsection{Selection of Preliminary Lessee}

Reclamation reviews proposals in accordance with Section 9(c) of the Reclamation Project Act of 1939, as amended by the 2013 Reclamation Small Conduit Hydropower Act (Reclamation 2014b). When selecting a preliminary lessee, Reclamation must ensure that the proposed project does not:

- Impair the efficiency of Reclamation-generated power or water deliveries

- Impact the structural integrity of the Reclamation conduit or dam

- Jeopardize public safety

- Negatively affect any other Reclamation project purpose (43 U.S.C. § 485h(c); Reclamation 2014).

Under the CSP, the proposal selection process for both dams and conduits gives priority to preference entities provided the entity is well-qualified to develop and provide for long-term operation and maintenance of the hydropower facility (Reclamation 2014b). A preference entity includes municipalities, public agencies, public corporations, tribes, ${ }^{29}$ cooperatives, and nonprofit organizations financed in whole or in part by loans made pursuant to the Rural Electrification Act of 1936 (Reclamation 2014b).

\subsection{Cost-Recovery Agreement}

Immediately after Reclamation issues a preliminary lease or in conjunction with the preliminary lease, Reclamation and the lessee enter into a cost-recovery agreement (Reclamation 2014b). Prior to any work conducted by Reclamation for the preliminary lease or the LOPP contract, the lessee must provide the necessary funding to cover all Reclamation costs pursuant to a costrecovery agreement (Reclamation 2014b). These costs include "any and all work related to federal and state environmental compliance, other statutory compliance, development, construction, operation and maintenance, inspections, security of the lessee's power facilities, review of all necessary studies, analyses, designs, plans, specification, and related material associated with the proposed hydropower facility, and any other related administrative costs" (Reclamation 2014b).

\subsection{Required Studies and Safety Plan}

After Reclamation grants a preliminary lease, Reclamation and the lessee work together to discuss (among other site-specific topics) public safety issues and identify all necessary studies ${ }^{30}$

\footnotetext{
${ }^{28}$ The preliminary lease also directs the potential lessee to enter into a cost recovery agreement to provide advance funding to the Reclamation before Reclamation incurs any cost for work related to the preliminary lease or LOPP. A preliminary lease is nontransferable and does not guarantee Reclamation will ultimately award a LOPP (Reclamation 2014b).

29 Tribes functioning as local governments qualify for preference under Section 9(c) of the Reclamation Project Act of 1939, as amended.

${ }^{30}$ Common study topics include public and dam safety impacts/modifications, site characteristics, existing facilities, land rights (e.g., acquisitions, easements, leases), hydraulics and hydrology, sedimentation study, water rights, project features and design, power production, environmental analysis, safety assessments, physical security and cybersecurity assessments, an operation and maintenance plan, and a project development plan and construction schedule (Reclamation 2014b).
} 
that must be conducted prior to executing the LOPP (Reclamation 2014b). The studies and safety plan must ensure:

- That the efficiency of Reclamation-generated power or water deliveries are not impaired

- The public safety, continued operation, and structural integrity of the Reclamation facility

- Compliance with the National Environmental Policy Act (NEPA), the Endangered Species Act (ESA), and the National Historic Preservation Act (NHPA) (Reclamation 2014b).

Consideration: Public safety issues that emerge after the preliminary lease phase of the $L O P P$ process could require adjustments to the location, design, construction, and/or operation of the lessee's project, which may increase development costs (Reclamation 2014b).

\subsection{Environmental Review}

The lessee must comply with NEPA, ESA, NHPA, and other statutory requirements ${ }^{31}$ during the preliminary lease phase and prior to execution of the LOPP. Reclamation incorporates terms and conditions resulting from NEPA, ESA, NHPA and other statutory compliance requirements within the LOPP (Reclamation 2014b).

Reclamation is the lead agency responsible for complying with the requirements of NEPA and the lessee is responsible for the costs associated with compliance. Reclamation may apply a categorical exclusion ${ }^{32}$ under NEPA ${ }^{33}$ to small conduit hydropower activities pursuant to the 2013 Reclamation Small Conduit Hydropower Act $^{34}$ or other project activities (Bureau of Reclamation Small Conduit Hydropower Development and Rural Jobs Act of 2013; Reclamation 2014b). When determining whether to apply the categorical exclusion, Reclamation considers whether the project is a small conduit hydropower project, or the project would:

- Utilize an existing dam or conduit

- Have a point of diversion and discharge in close proximity to the existing infrastructure and would not significantly affect the flow patterns of the water sources

- Increase or change the timing of diversions and discharges

- Have the same primary purpose for the infrastructure (e.g., most commonly irrigation) (Reclamation 2014b).

\footnotetext{
${ }^{31}$ Other statutory compliance may include compliance with the Clean Water Act, the Wild and Scenic Rivers Act, and the Fish and Wildlife Coordination Act.

${ }^{32}$ A “categorical exclusion" means a "category of actions which do not individually or cumulatively have significant effect on the human environment and which have been found to have no such effect in procedures adopted by a federal agency in implementation of [NEPA regulations] and...neither an environmental assessment nor an environmental impact statement is required” (40 C.F.R. § 1508.4).

33 Reclamation categorical exclusion 516 Department Manual 14.5C(3) (Reclamation 2014b).

${ }^{34}$ Consideration for a categorical exclusion does not guarantee that a categorical exclusion is appropriate for a proposed project. The project must be consistent with the terms of the categorical exclusion and have no extraordinary circumstances as described in 43 C.F.R. § 46.215. For cases in which the project does not meet the criteria of the categorical exclusion or in which any extraordinary circumstance exists, the project requires a higher level of NEPA evaluation (Reclamation 2014b).
} 
Consideration: Generally, LOPP projects do not qualify for the existing categorical exclusion because of egress or right-of-way requirements (e.g., transmission, roads, staging) (Reclamation 2018c).

If a categorical exclusion does not apply to the project, Reclamation prepares and issues either an Environmental Assessment (EA) ${ }^{35}$ and/or an Environmental Impact Statement (EIS) ${ }^{36}$ that examines alternatives and the likely effects to the human environment from the proposed project (40 C.F.R. $\S \S 1501.3$ - 1501.4) ${ }^{37}$ From Reclamation's experience, most LOPP projects are unlikely to rise to the level of an EIS (Reclamation 2018c). Figure 7 illustrates that as of December 2017, 15 of 36 active LOPP projects have completed NEPA review. Of those 15 projects, only one of those projects utilized a categorical exclusion. Of those 15 projects, 14 resulted in an EA and subsequent Finding of No Significant Impact (FONSI). No project required the preparation of an EIS.

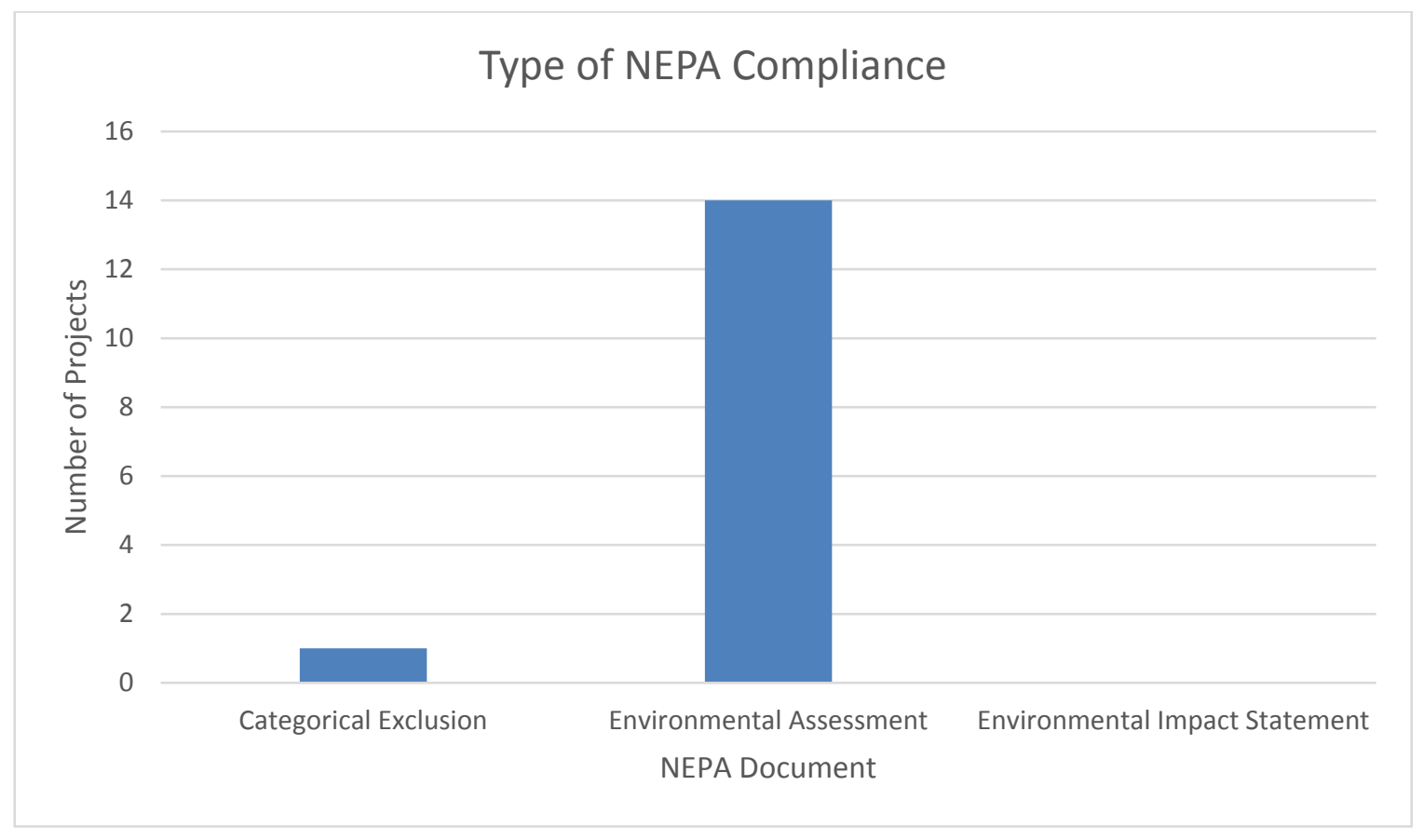

Figure 7. Lease of power privilege projects - type of NEPA compliance document

Reclamation may permit the lessee to prepare an EA. However, Reclamation must "make its own evaluation of the environmental issues and take responsibility for the scope and content of the [EA]” (40 C.F.R. § 1506.5[b]). If Reclamation determines an EIS is required, Reclamation either

\footnotetext{
${ }^{35}$ An EA is a public document that briefly provides evidence and analysis for determining whether to prepare an EIS or a Finding of No Significant Impact (40 C.F.R. § 1508.9).

${ }^{36}$ Compared to an EA, an EIS is a more comprehensive study in which Reclamation must "rigorously explore and objectively evaluate all reasonable alternatives” for the project (40 C.F.R. § 1502.14).

${ }^{37}$ Reclamation usually determines whether an EIS is required by preparing an EA. If, after completing the EA, Reclamation determines that the proposed project is likely to have a significant effect on the quality of the human environment, then an EIS is required. If Reclamation determines the project will not have a significant effect on the human environment, then a Finding of No Significant Impact is prepared (40 C.F.R. §§ 1501.3, 1501.4).
} 
prepares the EIS or hires a third-party consultant to prepare the EIS. ${ }^{38}$ The lessee may solicit third-party consultant candidates, but Reclamation makes the final selection decision and is ultimately responsible for the EIS preparation (e.g., scope and content). Reclamation must also independently evaluate the EIS prior to approval (40 C.F.R. § 1506.5[c]; CEQ 1981).

Consideration: The research for this report indicates that lessees prefer to have Reclamation prepare the requisite environmental document for NEPA compliance given: Reclamation's knowledge of the project site and location, cost-competitiveness, and relationship with the irrigation districts, water users associations, and other federal and state agencies (Reclamation 2018c).

\subsection{Execution of the Lease of Power Privilege}

Reclamation may execute a LOPP contact if the lessee meets all the terms and conditions of the preliminary lease. If Reclamation executes the LOPP, the lessee and Reclamation begin an iterative process of preparation and review of both the design drawings and specifications and the public health and safety program. For dams, the lessee has 1 year from the date of the execution of the LOPP to complete final design drawings, specifications, and other specified requirements, ${ }^{39}$ whereas for conduits the lessee has only 9 months. The preliminary lessee may begin construction of the project only after Reclamation accepts the design drawings and specifications as well as the safety and health program and provides notice to the lessee to proceed with construction (Reclamation 2014b). Reclamation allows a maximum of 4 years from the date of the preliminary lease to begin construction for dams and a maximum of 3 years for conduits $^{40}$ (Reclamation 2014b).

Reclamation can deny the issuance of a LOPP or withdraw a previously issued preliminary lease or LOPP at any time based on inadequate design information, environmental impacts, safety concerns, physical security concerns, cybersecurity concerns, detrimental impact to the Reclamation project, or any other legitimate reason as determined by the Reclamation regional director (Reclamation 2014b).

\subsubsection{Design Drawings and Specifications}

Upon execution of the LOPP, the lessee and Reclamation begin the process of preparation and review of the design drawings and specifications. The lessee must submit $60 \%, 90 \%$, final, and as-built design drawings and specifications to Reclamation (Reclamation 2011a). Reclamation

\footnotetext{
38 Third-party consultants must execute a disclosure statement to demonstrate to Reclamation that the consultant does not have an interest in the outcome of the proposal (40 C.F.R. § 1506.5[c]; CEQ 1981).

${ }^{39}$ Other specified requirements may include any requisite preconstruction submittals (e.g., final safety and health programs, operation plans, security plans, emergency action plans, as defined within the LOPP contract).

${ }^{40}$ The regional director may extend the time frames for just cause resulting from actions and/or circumstances that are beyond the control of Reclamation or the lessee (Reclamation 2014b).
} 
performs a fatal-flaw analysis ${ }^{41}$ along with additional reviews ${ }^{42}$ to ensure the project meets Reclamation's design standards required to protect water and related resources in an environmentally and economically sound manner (Reclamation 2012a).

Consideration: Initial design drawings and specifications submitted to Reclamation often lack the requisite detail required for approval. To improve the efficiency and cost associated with design drawings and specifications, the lessee should clarify the design and performance requirements with Reclamation prior to the preliminary lease (Reclamation 2018d).

\subsubsection{Health and Safety Program}

The lessee and Reclamation begin the process of preparation and review of the health and safety program upon the execution of the LOPP. The lessee must prepare a safety and health program, which undergoes review by Reclamation and often requires subsequent revision by the lessee (Reclamation 2011a).

Consideration: Comprehensive risk assessments and studies help inform the development of the health and safety program. A comprehensive risk assessment should include the identification, remediation, and/or removal of any hazardous material associated with the project. Identifying hazardous materials and other health and safety concerns early on in the LOPP process may reduce project uncertainties (Reclamation 2018d).

\subsubsection{Notice to Proceed}

Upon approval of the design drawings, specifications, and the health and safety program, Reclamation issues a Notice to Proceed, thereby allowing the lessee to begin construction (Reclamation 2011a).

\footnotetext{
${ }^{41}$ A "fatal flaw analysis" is a design review that only looks at the safety and regulatory requirements for the design. A fatal flaw analysis ensures that the project, operating as intended or completely failing, will have no impact on Reclamation facility operations or water delivery obligations (Reclamation 2018d).

${ }^{42}$ Additional reviews can include but are not limited to: legal reviews regarding use of water, failure analysis of the proposed project, U.S. Environmental Protection Agency reviews of hazardous material abatement plans, and NEPA reviews (Reclamation 2018d).
} 


\section{Lease of Power Privilege Case Studies and Timelines}

This section discusses the experiences and considerations of two hydropower projects that went through the Reclamation LOPP process and illustrates average timelines for hydropower projects to complete certain phases of the LOPP process.

\subsection{Case Studies}

The case studies provided in this section detail two projects that Reclamation issued LOPPs for the use of Reclamation lands and assets to construct, operate, and maintain a hydroelectric facility. The case studies represent a conduit hydropower project located in western Colorado and a hydropower dam project located in eastern Colorado. The information for the case studies was obtained through developer interviews, Reclamation staff interviews and documents, and publicly available material.

\subsubsection{South Canal Conduit Hydroelectric Project Drop 1 and 3}

The South Canal Conduit Hydroelectric Project at Drop 1 and 3 (South Canal Project) is located on the South Canal ${ }^{43}$ in Montrose, Colorado. The project's two small conduit hydropower turbines, totaling 7.5 MW, generate 27,000 MWh of electricity annually, providing electricity for approximately 3,000 homes in the Delta-Montrose Electric Association ${ }^{44}$ (DMEA) service territory (DMEA 2018b).

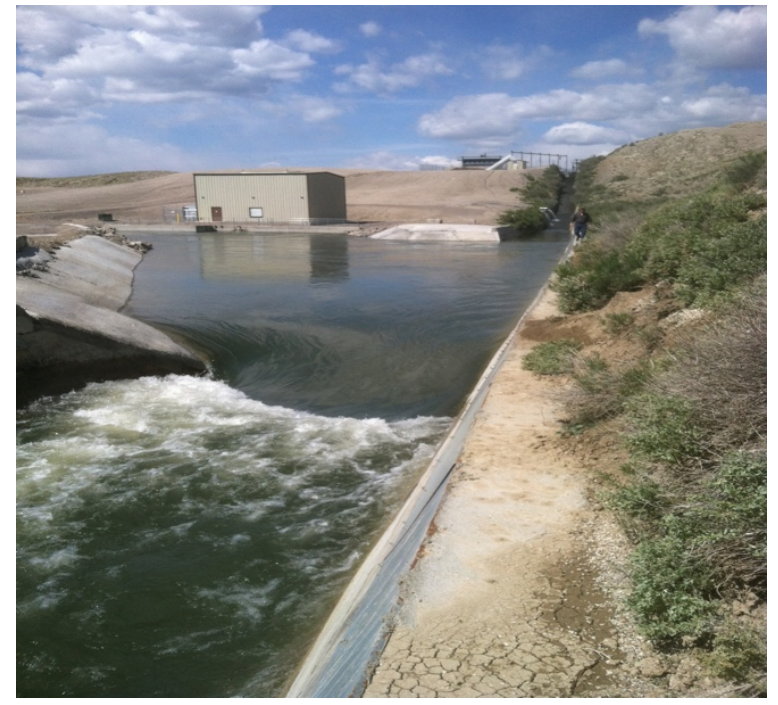

Figure 8. South Canal Drop 3 Hydroelectric Project - 3.5 MW. Photo courtesy of DMEA

\footnotetext{
43 The South Canal is an 11-mile canal with 12 vertical drops that draw water from the Gunnison River through the Gunnison Tunnel on Colorado's Western Slope to irrigate the Uncompahgre Valley before releasing the water to the Uncompahgre River (Reclamation 2018b).

${ }^{44}$ Delta-Montrose Electric Association is a member-owned local electric cooperative serving Montrose, Delta, and Gunnison counties in Colorado (DMEA 2018b).
} 


\subsubsection{Initiating the Lease of Power Privilege Process}

In August 2009, DMEA, in partnership with the Uncompahgre Valley Water Users Association (UVWUA), ${ }^{45}$ filed an FRD with Reclamation to initiate the LOPP process for the South Canal Project (DMEA 2018a) ${ }^{46}$ Thereafter, Reclamation published a Request for Proposals in the Federal Register for hydropower generation at the South Canal (Reclamation 2012b). To gain support for the South Canal Project, DMEA sought to partner with UVWUA (DMEA 2018a). As the irrigation district operator and manager for the Uncompahgre Irrigation Project ${ }^{47}$ with senior water rights to the South Canal, UVWUA was a natural partner for the project (DMEA 2018a).

\subsubsection{Competitive Solicitation Process and Project Proposal}

After submitting the FRD, DMEA and UVWUA went through the competitive solicitation LOPP process. Reclamation's well-defined proposal requirements made developing the South Canal Project proposal relatively straightforward. With support from UVWUA, DMEA was the only developer to submit a proposal to Reclamation. Soon after the close of the CSP, Reclamation began LOPP contract negotiations with DMEA (DMEA 2018a). At that time, there was no formal preliminary lease process. However, negotiations between UVWUA, DMEA, and Reclamation provided for cost reimbursement to Reclamation for NEPA compliance, engineering review, and development of the LOPP (Reclamation 2012b).

\subsubsection{Negotiation (Preliminary Lease under the Current LOPP Regulatory Process)}

The negotiation phase of the project required extensive outreach and coordination with federal agencies, state agencies, the community, local government, private land owners, and recreation and environment groups, among other stakeholders. Recognizing past public resistance and the subsequent failed attempts at developing hydropower on the South Canal, DMEA and UVWUA made a concentrated effort to engage the public and other stakeholders early and often (DMEA 2018a).

\section{Required Studies, Safety Plan, and Environmental Review}

DMEA and UVWUA worked with Reclamation to hold multiple public meetings prior to the formal NEPA scoping process to identify potential studies required for the project and to discuss public safety and environmental concerns. During the formal scoping process ${ }^{48}$ conducted in March 2011, DMEA and UVWUA continued to engage stakeholders about the project (DMEA 2018a; Reclamation 2012b).

\footnotetext{
45 The UVWUA was developed in 1902 to organize a plan to divert the Gunnison River into the Uncompahgre Valley (i.e., the Uncompahgre Project). UVWUA has managed and operated the Uncompahgre Project since 1932 (Reclamation 2018b).

46 The South Canal Conduit Hydroelectric Project at Drop 1 and 3 was developed before the revised LOPP Directives and Standards Manual was published in 2012 and before the passage of the Reclamation Small Hydropower Development Act of 2013.

${ }^{47}$ The Uncompahgre Project was authorized in 1903 pursuant to the Reclamation Act of 1902. The Uncompahgre Project stretches across much of western Colorado and draws water from the Uncompahgre and Gunnison Rivers to irrigate over 66,000 acres in Delta, Gunnison, and Montrose counties in Colorado (Reclamation 2018b).

${ }^{48}$ The formal scoping process included notice to over 50 local, state, interested organizations and federal agencies about the public meeting regarding the South Canal Project (Reclamation 2012c).
} 
During the formal scoping process, stakeholders identified a number of potential issues, including:

- Visual impacts from new power lines

- Potential impacts to existing water deliveries

- Potential impacts to fisheries in the Gunnison River

- Changes in diversions

- General support for renewable energy

- Potential impacts to the Uncompahgre Irrigation Project

- Potential impacts to DMEA and UVWUA members

- Potential impacts to local wildlife, including endangered plants

- Protection of cultural resources (Reclamation 2012b).

The South Canal Project's modest size and utilization of existing infrastructure helped ease stakeholder concerns about the environmental impacts of the project. However, balancing all the distinct interests and complying with NEPA presented challenges. For example, recreational fishing turned out to be more of an issue than expected. Even though the South Canal is not a designated recreational area, the canal had been a popular fishing spot for the local community and a number of stakeholders were concerned about losing their "fishing hole" (DMEA 2018a). DMEA and UVWUA held a number of meetings with Reclamation to come up with a solution that adequately addressed the fishing concern (DMEA 2018a). Ultimately, DMEA and UVWUA worked with the local community to add a 1.25-mile recreational fishing area on the Uncompahgre River (DMEA 2018a).

Other mitigation measures included, but were not limited to, the following:

- Hydropower production was restricted from November through February to avoid impacts to aquatic habitat conditions and irrigation supplies

- A Memorandum of Agreement with the State Historic Preservation Office was created to mitigate cultural resource impacts to the South Canal, which is listed on the National Register of Historic Places

- Construction and operation of an electronic fish barrier at the entrance of the Gunnison Tunnel to deter fish from entering the tunnel from the Gunnison River

- Compliance with diversion guidance to prevent increased diversion volumes from hydropower production

- Compliance with the U.S. Fish and Wildlife Service's Avian Protection Plan Guidelines for the construction of new power lines and power poles (Reclamation 2012c).

DMEA and UVWUA elected to have Reclamation staff rather than a third-party consultant prepare the EA. Reclamation issued a final EA and a subsequent FONSI in February 2012. DMEA and UVWUA found that Reclamation's knowledge of the project site, familiarity with the community, and relationship with the irrigation district and other federal and state agencies made Reclamation the best candidate to prepare the EA. Reclamation was also cost-competitive with other third-party quotes (DMEA 2018a). 


\subsubsection{Execution of the Lease of Power Privilege}

In March 2012, Reclamation executed a LOPP for the South Canal Project after DMEA and UVWUA met all negotiated terms and conditions. ${ }^{49}$ The LOPP authorized a 40 -year use ${ }^{50}$ of the federal lands, facilities, and the Uncompahgre Irrigation Project water to construct, operate, and maintain the 7.5-MW South Canal Hydropower Project (Reclamation 2012b).

\section{Design Drawings, Specifications, and Health and Safety Program}

To begin the preparation of the design drawings and specifications, DMEA and UVWUA hired an Engineer, Procurement, and Construct contractor who was well-versed in the development requirements for hydroelectric facility installations. The contractor worked with the Reclamation area office on a biweekly basis through an iterative process of preparing and reviewing both the design drawings and specifications. The contractor's expertise in hydropower development fostered a smooth and efficient design drawings and specifications process (DMEA 2018a).

For the final safety and health program, Reclamation provided a broad outline of the requirements, and DEMA and UVWUA worked with an insurer to fill in the details required for approval (DMEA 2018a).

\subsubsection{Construction Timeline and Online Date}

DMEA and UVWUA started construction of the 7.5-MW South Canal Project in late May 2012 and the project came online in the summer of 2013 (DMEA 2018c). The electricity generated from the South Canal Project provides UVWUA and DMEA with a source of revenue to defray annual operating costs (Reclamation 2012b). The South Canal Project also creates a secondary use for the water, thereby strengthening UVWUA's water rights and the electricity revenue from the project offsets maintenance costs for the Uncompahgre Irrigation Project (DMEA 2018a). In addition, the South Canal Project diversifies DMEA's generating mix and helps DMEA meet the requirements of Colorado's renewables portfolio standard ${ }^{51}$ (Reclamation 2012b).

\subsubsection{Granby Dam Hydroelectric Project}

The Granby Dam Hydroelectric Project is located at the outlet of the Lake Granby Dam ${ }^{52}$ on the Colorado River in Grand County, Colorado. The 1.2-MW project generates 5,000 MWh of electricity annually, providing electricity for approximately 600 homes a year within Mountain Parks Electric's ${ }^{53}$ service territory (Mountain Parks Electric 2018a).

\footnotetext{
${ }^{49}$ One of the primary conditions of the LOPP is that the South Canal Project must accommodate existing contractual water delivery, and environmental commitments related to the operation and maintenance of the South Canal and the Uncompahgre River (Reclamation 2012b).

${ }^{50}$ In exchange for the use of federal lands, facilities, and the Uncompahgre Project, the LOPP requires DMEA and UVWUA to make annual lease payments of 3 mills per kilowatt-hour of gross energy produced by the South Canal Project to Reclamation (Reclamation 2012b).

${ }^{51}$ Colorado's renewables portfolio standard requires that electric cooperatives serving fewer than 100,000 electric meters obtain $10 \%$ of their retail electricity sales from eligible renewable energy resources by 2020 (COLO. REV. STAT. § 40-2-124[1][c][V]). Colorado's renewables portfolio standard includes new hydropower with a nameplate capacity of $10 \mathrm{MW}$ or less, and existing hydropower of 30 MW or less (Colo. Rev. STAT. § 40-2-124[1][a][VII]).

${ }^{52}$ Lake Granby and Granby Dam are the principal storage features of the Colorado-Big Thompson Irrigation Project, collecting water from the flow of the Colorado River and water pumped from Willow Creek (Reclamation 2018e).

${ }^{53}$ Mountain Parks Electric is a member-owned electric cooperative serving all of Grand and Jackson counties, and parts of Routt, Summit, and Larimer counties in Colorado (Mountain Parks Electric 2018b).
} 


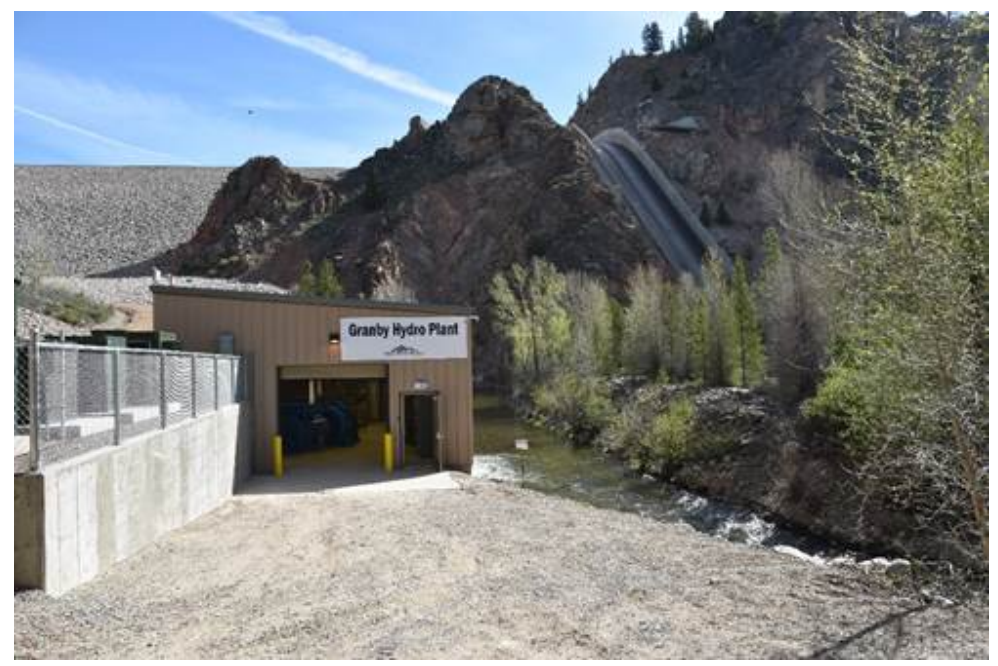

Figure 9. Granby Dam Hydroelectric Project - 1.2 MW. Photo courtesy of NWCD

\subsubsection{Initiating the Lease of Power Privilege Process}

In September 2010, American Renewables filed an FRD with Reclamation initiating the LOPP process for the Granby Dam Project (Northern Water Conservancy District [NWCD] 2018a). ${ }^{54}$ Thereafter, in April 2011, Reclamation published a request in the Federal Register for proposals for hydropower development at the Granby Dam (Reclamation 2015a). NWCD ${ }^{55}$ responded to the Federal Register notice and also filed an FRD with Reclamation expressing interest in developing the Granby Dam Project (NWCD 2018a). As the irrigation district operator and manager of the Colorado-Big Thompson Project, ${ }^{56}$ which includes the Granby Dam, NWCD had a natural interest in developing the project (NWCD 2018a).

\subsubsection{Competitive Solicitation Process and Project Proposal}

After submitting the FRD, NWCD went through the competitive solicitation LOPP process. Reclamation's well-defined proposal requirements and the preliminary engineering feasibility studies that NWCD had previously conducted made developing the Granby Dam Project proposal relatively straightforward (NWCD 2018a). Although American Renewables filed the initial FRD, thereby initiating the LOPP process, ultimately NWCD was the only entity to submit a project proposal to Reclamation (NWCD 2018a). As a preference entity and the Granby Dam operator, NWCD had a natural interest in developing the project. In October 2011, Reclamation issued a preliminary lease to NWCD (Reclamation 2015a). In June 2012, Reclamation extended the preliminary lease to October 2015 (Reclamation 2015a). The preliminary lease provided for

\footnotetext{
54 The Granby Dam Hydroelectric Project was developed before the revised LOPP Directives and Standards Manual was published in 2012 and before the passage of the Reclamation Small Hydropower Development Act of 2013.

${ }_{55}$ Northern Water Conservancy District is a public agency created in 1937 to contract with the federal government to build the Colorado-Big Thompson Irrigation Project (NWCD 2018b).

56 The Colorado-Big Thompson Project was authorized in 1937 pursuant to the Department of Interior Appropriations Act of 1938. The project is one of the largest and most complex natural resource developments undertaken by Reclamation consisting of over 100 structures, including the Granby Dam, integrated into a trans-mountain water diversion system. The Colorado-Big Thompson Project stores, regulates, and diverts water from the Colorado River on the Western Slope to eight Colorado counties on the Eastern Slope of the Rocky Mountains. The Northern Water Conservancy District and Reclamation jointly operate and maintain the Colorado-Big Thompson Project (Reclamation 2018e; NWCD 2018b).
} 
cost reimbursement to Reclamation for NEPA compliance, engineering review, and development of the LOPP (Reclamation 2015b).

\subsubsection{Preliminary Lease}

The preliminary lease phase of the project required extensive outreach and coordination with federal agencies, state agencies, the community, local government, private land owners, and recreation and environment groups, among other stakeholders (NWCD 2018a).

\section{Required Studies, Safety Plan, and Environmental Review}

NWCD and Reclamation conducted internal scoping to identify potential studies required for the project and to discuss public safety and environmental concerns. During the scoping process, NWCD and Reclamation identified a number of potential issues, including:

- Visual impacts from new power lines

- Potential impacts to existing water deliveries

- Potential impacts to fisheries in the Colorado River

- Changes in diversions

- General support for renewable energy

- Potential impacts to local wildlife, including nesting osprey

- Potential impacts to wetland resources

- Protection of cultural resources (Reclamation 2015a).

NWCD was not required to hold a public meeting regarding the proposed project but NWCD did interact with the public informally. The Granby Dam Project's modest size and the utilization of existing infrastructure helped ease stakeholder concerns about the environmental impacts of the project. However, balancing all the distinct interests and complying with NEPA presented challenges. For instance, NWCD spent a lot of time working with the U.S. Forest Service (USFS) and the State Historical Preservation Office to address national forest resource and historic resource concerns (NWCD 2018a). The Granby Dam Project is located within the Arapaho National Recreation Area ${ }^{57}$-a world-class recreation area ${ }^{58}$ managed by USFS (Reclamation 2015a). To comply with USFS interests, ${ }^{59}$ NWCD worked with USFS to limit hiking access and fishing restrictions during construction and to ensure recreational access to Lake Granby (Reclamation 2015a; NWCD 2018a). NWCD also worked closely with the State Historical Preservation Office to address concerns associated with a number of cultural resources within 1 mile from the area of potential effects in accordance with Section 106 of the NHPA (Reclamation 2015a; NWCD 2018a).

Other mitigation measures included, but were not limited to, the following:

\footnotetext{
57 The Arapaho National Recreation Area is comprised of 35,235 acres in Grand County, Colorado, within the Arapaho and Roosevelt National Forests (Reclamation 2015a).

${ }^{58}$ The Arapaho National Recreation Area is a world-class place to boat, camp, hike, fish, ice fish, snowmobile, view wildlife, ride horses, and hold events (Reclamation 2015a).

${ }^{59}$ USFS lands must be "managed in accordance to laws and regulations that require that national forest lands provide for: public recreation and enjoyment, and conservation and development of the scenic, natural, historic, and pastoral values of the area...” (Reclamation 2015a).
} 
- A Section 404 CWA Nationwide Permit from the U.S. Army Corps of Engineers to address discharges of dredge/fill material associated with construction activities that disturbed herbaceous wetlands

- Coordination with USFS to minimize visual impacts to Arapaho National Recreation Area consistent with USFS's visual management system

- An intergovernmental agreement with Grand County to ensure that water temperature of the Colorado River would not exceed standards for cold water aquatic species

- Construction activity restrictions from May through September to avoid impacts to active osprey nesting

- Compliance with U.S. Fish and Wildlife Service's Avian Protection Plan Guidelines for the construction of new power lines and power poles (Reclamation 2015b).

NWCD elected to have Reclamation staff rather than a third-party consultant prepare the EA. Reclamation issued a final EA and a subsequent FONSI in March 2015 (Reclamation 2015a, 2015b). NWCD found that Reclamation's knowledge of the project site, familiarity with the community, and relationship with the irrigation district and other federal and state agencies made Reclamation the best candidate to prepare the EA. Reclamation was also cost-competitive with other third-party quotes (NWCD 2018a).

\subsubsection{Execution of the Lease of Power Privilege}

In March 2015, Reclamation issued a LOPP for the Granby Dam Project after NWCD met all the terms and conditions of the preliminary lease (NWCD 2018a). The LOPP authorizes a 40-year use $^{60}$ of the federal lands, facilities, and the Colorado-Big Thompson Irrigation Project water to construct, operate, and maintain the 1.2-MW Granby Dam Hydroelectric Project (Reclamation 2015c).

\section{Design Drawings, Specifications, and Health and Safety Program}

To begin the preparation of the design drawings and specifications, NWCD hired an engineering firm who worked directly with the Reclamation Technical Service Center (NWCD 2018a). The engineering firm worked with Reclamation through an iterative process of preparing and reviewing the design drawings and specifications (NWCD 2018a).

For the final safety and health program, Reclamation provided the engineering firm with the yellow book ${ }^{61}$ requirements. The final safety and health program took two iterations before approval (NWCD 2018a).

\subsubsection{Construction Timeline and Online Date}

NWCD started construction of the 1.2-MW Granby Dam Project in the spring of 2015 and the project came online in May 2016 (NWCD 2018c). The electricity generated from the Granby Dam Project provides NWCD with a source of revenue to defray annual operating costs (Reclamation 2015a). The Granby Dam Project also creates a secondary use for the water, thereby strengthening NWCD's water rights. Further, the electricity revenue from the project

\footnotetext{
${ }^{60}$ In exchange for the use of federal lands, facilities, and the Colorado-Big Thompson Irrigation Project, the LOPP requires NWCD to make annual lease payments of 2 mills per kilowatt-hour of gross energy produced by the Granby Dam Hydroelectric Project to Reclamation (Reclamation 2015c).

61 The yellow book requirements are Reclamation’s Safety and Health Standards (Reclamation 2014a).
} 
offsets maintenance costs for the Colorado-Big Thompson Irrigation Project (NWCD 2018a; Reclamation 2015a). In addition, the Granby Dam Project diversifies Mountain Parks Electric's generating mix and helps it meet the requirements of Colorado's renewables portfolio standard (Reclamation 2015a). ${ }^{62}$

\subsection{Lease of Power Privilege Process Timelines}

This section provides timeline information for Reclamation dam and conduit projects that have received a LOPP contract as of December 2017. The data represented in the timelines analysis was obtained through Reclamation staff interviews and documents provided for this report. See Appendix A for a list of the 14 LOPP projects used for the timelines analysis.

Figure 10 and Figure 11 depict timelines and timeline averages between the project initiation date and the LOPP contract date for 14 of the 36 active LOPP projects studied. The initiation date for the purposes of this report refers to the date that Reclamation posts notice in the Federal Register requesting proposals for hydropower developed as part of the CSP or the date Reclamation receives proposals for development from an irrigation district or water users association exercising its right-of-first refusal to develop hydropower at a Reclamation conduit. Active LOPP projects include those that have received a LOPP and that are online and those that have been identified and are at some stage of the LOPP process (e.g., request for development, drafting public solicitation, preliminary lease, LOPP contract). ${ }^{63}$

Figure 12 and Figure 13 depict the timelines and timeline averages between the project initiation date and the project online date for 10 of the 36 active LOPP projects studied (Reclamation 2017a). The project online date for the purposes of this report is the date the hydropower project began operating and generating electricity.

\subsubsection{Lease of Power Privilege Project Initiation to Contract Execution Timelines}

Figure 10 depicts timelines between the project initiation date and LOPP contract date for 14 of the 36 LOPP projects studied. Initiation dates are available for 33 of the 36 projects studied. ${ }^{64}$ Of those 33 projects with available initiation dates Reclamation has awarded 14 of those projects with LOPP contracts. ${ }^{65}$ The timelines of these 14 projects are in chronological order and are color coded to delineate those projects initiated before and after Reclamation established a streamlined LOPP regulatory process in September 2012. ${ }^{66}$ Of those 14 projects, 8 were initiated

\footnotetext{
${ }^{62}$ Colorado's renewables portfolio standard requires that electric cooperatives serving fewer than 100,000 electric meters obtain $10 \%$ of their retail electricity sales from eligible renewable energy resources by 2020 (COLO. REV. STAT. § 40-2-124[1][c][V]). Colorado's renewables portfolio standard includes new hydropower with a nameplate capacity of $10 \mathrm{MW}$ or less, and existing hydropower of 30 MW or less (COLO. REv. STAT. § 40-2-124[1][a][VII]).

${ }^{63}$ An additional three canal projects in Montana have been identified but are currently inactive (Reclamation 2017a).

${ }^{64}$ Initiation dates for three projects that Reclamation granted a LOPP for in 1933, 1988, and 1995 are unavailable and therefore excluded from the report's data analysis (Reclamation 2017a).

${ }^{65}$ Of the 33 active projects with known initiation dates, 19 are in some phase of the LOPP regulatory process but have not yet been awarded a LOPP contract (Reclamation 2017a).

${ }^{66}$ Reclamation simplified the LOPP regulatory process in 2012. Reclamation's Lease of Power Privilege Directives and Standards Manual initially published in September 2012 detailed the changes made to the LOPP regulatory process. The Lease of Power Privilege Directives and Standards Manual was revised in February 2014 to reflect the Reclamation Small Hydropower Development Act of 2013 requirements. The manual was revised again in September 2014 to implement public comment feedback and again in December 2016 to clarify time frames, cybersecurity requirements, and annual charge methodology (Reclamation 2018a).
} 
before the streamlined LOPP process took effect and 6 projects were initiated afterwards and went through the current regulatory process.

The Jordanelle Dam Hydroelectric Project (13 MW) in Utah and the Pueblo Dam Hydroelectric Project (9 MW) in Colorado were initiated prior to the current streamlined LOPP process and took approximately 8.5 years and 6 years, respectively, from the date of initiation to receive a LOPP contract. All of the projects initiated after the current LOPP process went into effect have received a LOPP contract in approximately 1 year or less from the initiation date. ${ }^{67}$ The South Canal Drop 2 Hydroelectric Project (987 kW) in Colorado went through the current streamlined LOPP process and received a LOPP contract within 6.5 months from the initiation date of the project (Reclamation 2017a).

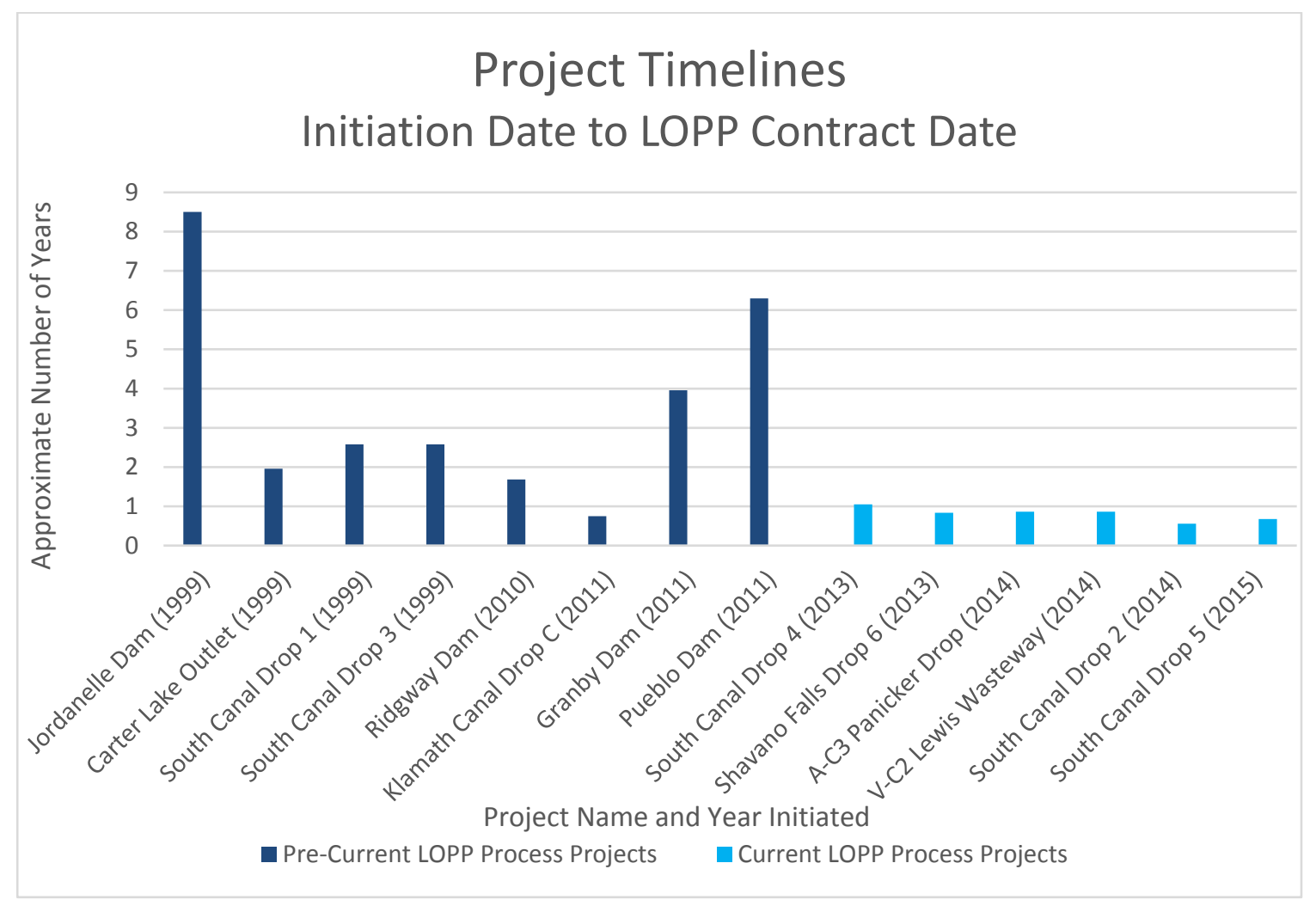

Figure 10. Lease of power privilege projects - timelines from initiation date to contract date

\subsubsection{Lease of Power Privilege Project Initiation to Contract Execution Timeline Averages}

Figure 11 depicts the average timelines between the project initiation date and the LOPP contract date for projects initiated before the current streamlined LOPP process and those projects initiated after the current LOPP process went into effect. The timelines for the eight projects initiated before the current LOPP process ranged between 9 and 102 months. The mean timelines for these projects is approximately 42.5 months and the median is 31 months. The timelines for

${ }^{67}$ All of these initiated projects are sited on Reclamation conduits. 
the six projects that utilized the current LOPP process ranged between 6.5 and 13 months. The mean timelines for these projects is approximately 9.5 months and the median is 10 months.

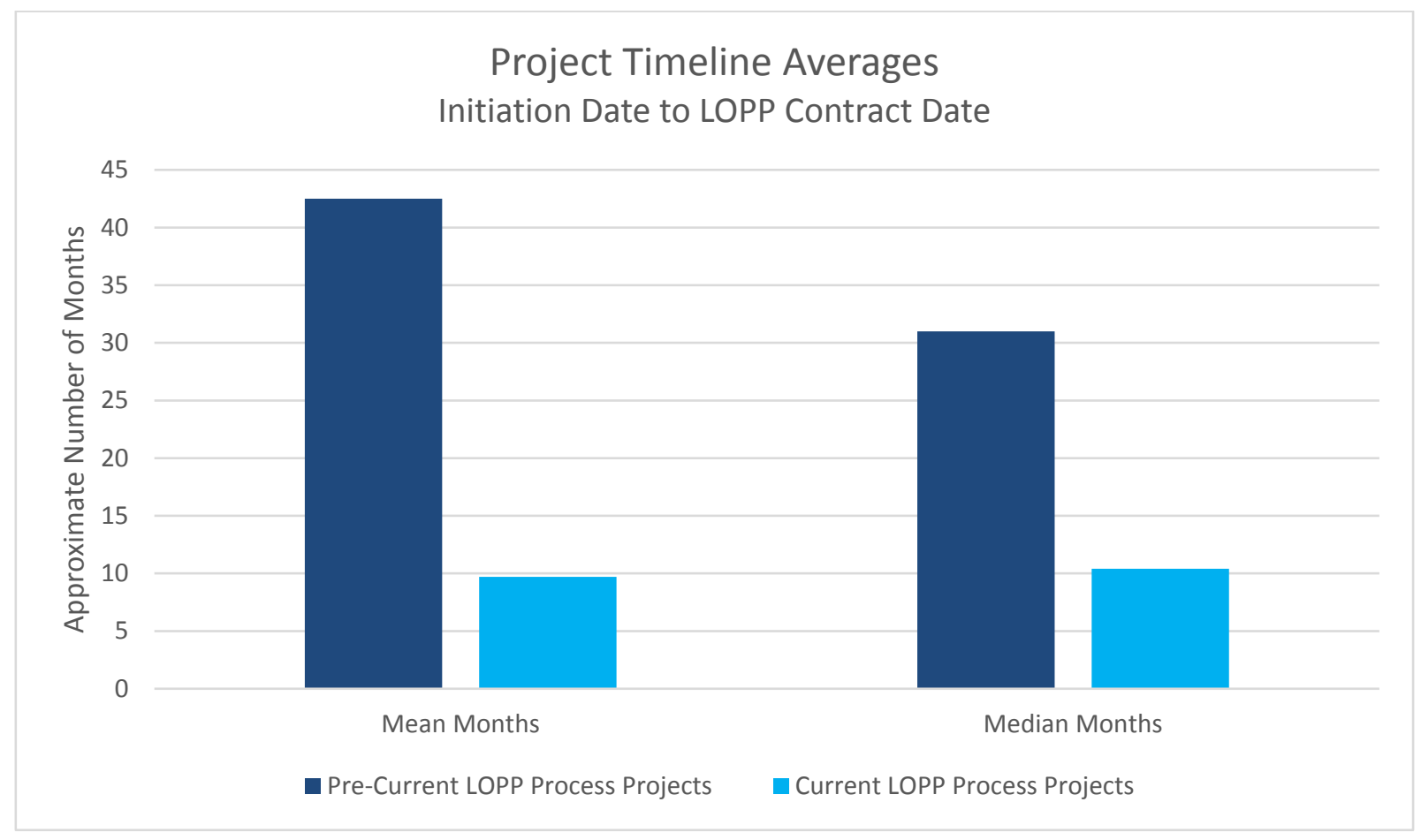

Figure 11. Lease of power privilege projects - average timelines from initiation date to contract date

\subsubsection{Lease of Power Privilege Project Initiation Date to Online Date Timelines}

Figure 12 depicts timelines between the project initiation date and the project online date for 10 of the 36 active LOPP projects studied. ${ }^{68}$ Initiation dates are available for 33 of the 36 projects studied. ${ }^{69}$ Of those 33 projects, 10 are online. ${ }^{70}$ The timelines of these 10 projects are in chronological order and color coded to delineate those projects initiated before and after Reclamation established the current streamlined LOPP process. Of those 10 projects, seven were initiated before the current LOPP process took effect and three projects were initiated afterwards and went through the current LOPP process.

\footnotetext{
${ }^{68}$ Active LOPP projects include those that have received a LOPP and that are online and those that have been identified and are at some stage of the LOPP process (e.g., request for development, drafting public solicitation, preliminary lease, LOPP contract). An additional three canal projects in Montana have been identified but are currently inactive.

${ }^{69}$ Initiation dates for three projects that Reclamation granted a LOPP for in 1933, 1988, and 1995 are unavailable and therefore excluded from the report's data analysis (Reclamation 2017a).

${ }^{70}$ Of the 33 active projects with known initiation dates, 23 are in some phase of the LOPP regulatory process but are not yet online as of December 2017 (Reclamation 2017a).
} 


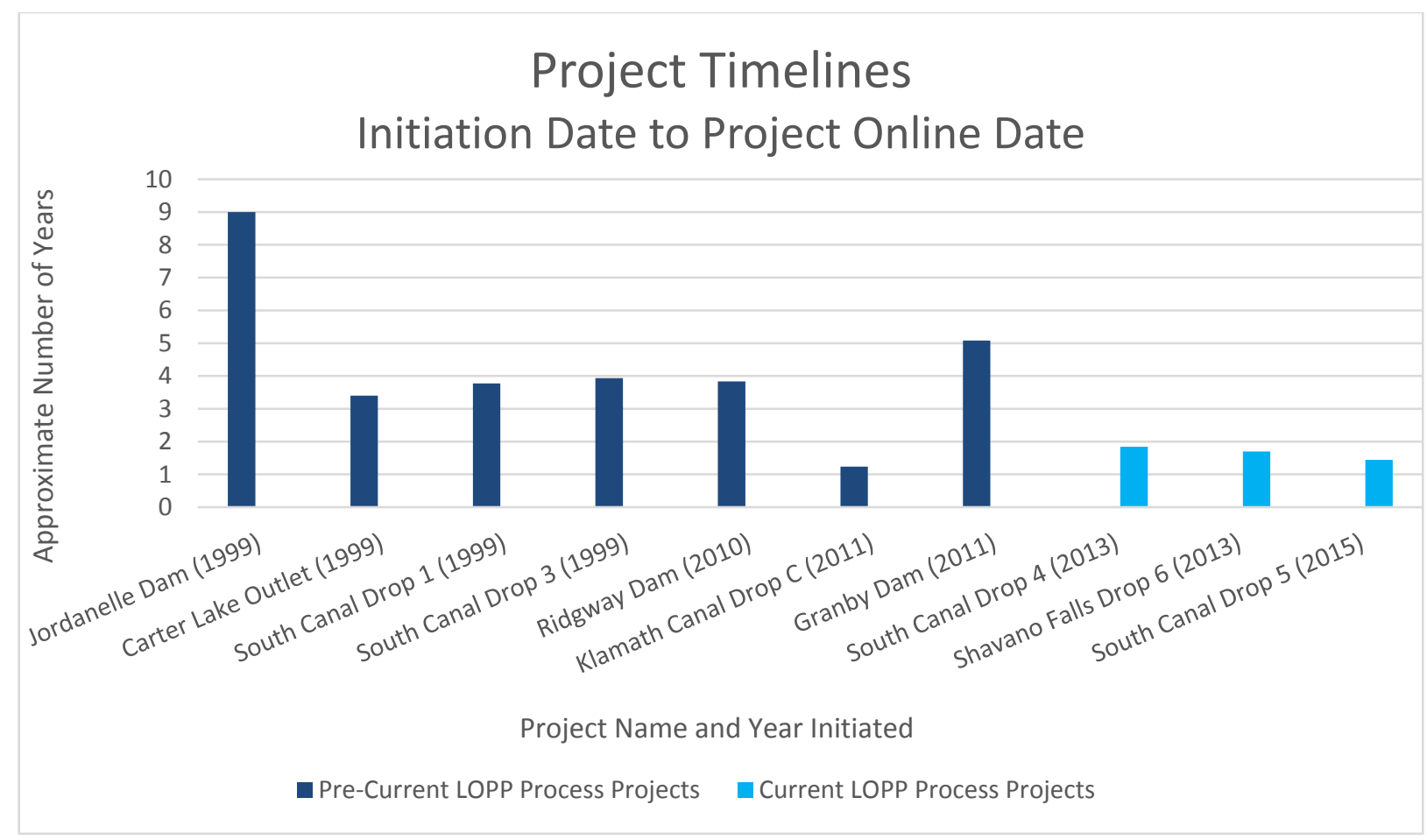

Figure 12. Lease of power privilege projects - timelines from initiation date to contract date

\subsubsection{Lease of Power Privilege Project Initiation to Project Online Date Timeline Averages}

Figure 13 depicts the average timelines between the project initiation date and the project online date for projects initiated before the current streamlined LOPP process and those projects initiated afterwards. The timelines for the seven projects that are online and that were initiated before the current LOPP process ranged from 15 to 108 months. The mean timelines for these projects is approximately 51 months and the median is 46 months. The timelines for the three projects that are online and went through the current LOPP process ranged from 17 to 22 months. The mean timelines for these projects is approximately 20 months and the median is also 20 months. 


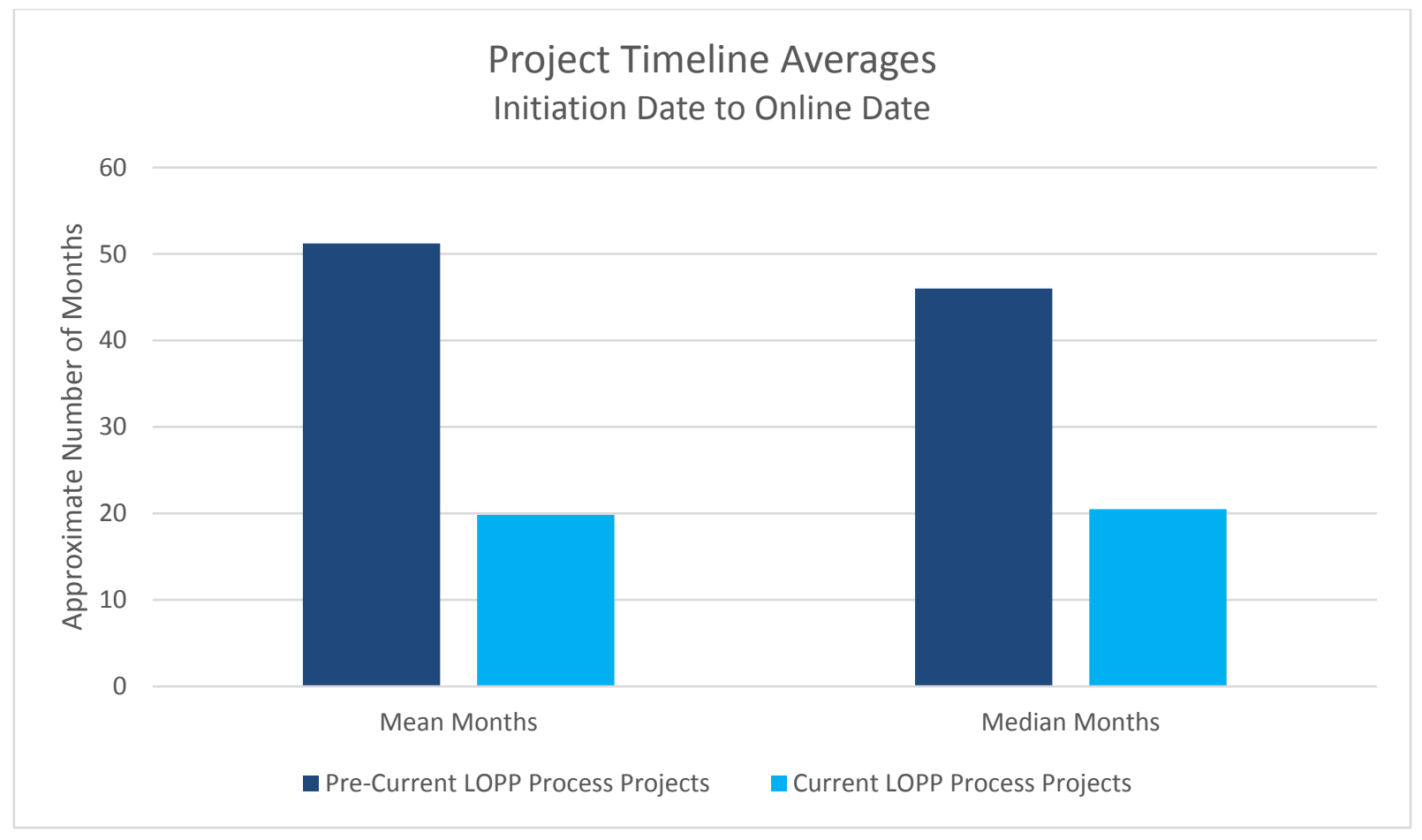

Figure 13. Lease of power privilege projects - average timelines from initiation date to online date 


\section{Conclusion}

Reclamation's efforts to streamline the LOPP regulatory process, beginning in 2012, coupled with federal statutory changes in 2013 have decreased processing timelines and have led to an increased interest in nonfederal hydropower development on Reclamation dams and conduits. Prior to streamlining efforts, the timeline from the project initiation date to the LOPP contract date ranged from 9 to 102 months, while the mean and median timelines for these projects were approximately 42.5 and 31 months, respectively. After the streamlined regulatory process took effect, the timeline from the project initiation date to the LOPP contract date ranged between 6.5 and 13 months, while the mean and median timelines for these projects was approximately 9.5 and 10 months, respectively. During the last 5 years, 23 of the 36 total LOPP projects were initiated and are at some phase of development. As of December 2017, 13 LOPP projects with an installed capacity of nearly $46 \mathrm{MW}$ are online, whereas the remaining 23 LOPP projects with a total nameplate capacity of approximately 30 MW have been initiated. 


\section{References}

Reclamation (U.S. Bureau of Reclamation). 2011a. Bureau of Reclamation: Lease of Power Privilege Flowchart - Lease of Power Privilege Contract through the End of Construction. https://www.usbr.gov/power/LOPP/PL\%20113-

24\%20Revision/LOPP\%20through\%20End\%20of\%20Construction.pdf. (Accessed February 21, 2018).

2011b. Reclamation Hydropower Resource Assessment at Existing Reclamation Facilities. (March 2011).

https://www.usbr.gov/power/AssessmentReport/USBRHydroAssessmentFinalReportMarch2011. pdf.

2012a. “Design Standards No. 1.” (May 18, 2012).

https://www.usbr.gov/tsc/techreferences/designstandards-datacollectionguides/finalds-pdfs/DS11and2.pdf.

2012b. Final Environmental Assessment - South Canal Hydropower Project. (February 2012). https://www.usbr.gov/uc/envdocs/ea/SoCanal/FinalEA.pdf.

2012c. Finding of No Significant Impact - South Canal Hydropower Project. (February 2012). https://www.usbr.gov/uc/envdocs/ea/SoCanal/fonsi.pdf.

2012d. Site Inventory and Hydropower Energy Assessment of Reclamation Owned Conduits - Supplement to the Hydropower Resource Assessment at Existing Reclamation Facilities Report. (March 2012). https://www.usbr.gov/power/CanalReport/FinalReportMarch2012.pdf.

2014a. Reclamation Safety and Health Standards. (July 2014)

https://www.usbr.gov/ssle/safety/RSHS-all.pdf.

2014b. Reclamation Manual Directive and Standards (FAC 04-08). (September 17, 2014) (minor revisions approved December 20, 2016). https://www.usbr.gov/recman/fac/fac04-08.pdf.

2015a. Final Environmental Assessment - Granby Hydropower Project. (March 2015). https://www.usbr.gov/gp/ecao/nepa/granby_ea_lopp.pdf.

2015b. Finding of No Significant Impact - Granby Hydropower Project. (March 2015). https://www.usbr.gov/gp/ecao/nepa/granby_fonsi_lopp.pdf.

2015c. Lease of Power Privilege Between the United States of America and the Northern Water Hydropower Water Activity Enterprise and Owned by the Northern Colorado Water Conservancy District, for the Construction, Operation, and Maintenance of the Development of Hydroelectric Power at Granby Dam. (March 2015).

2017a. “Lease of Power Privilege Development Summary for NREL Report.” (December 8 2017) (Spreadsheet detailing every LOPP project to date, crafted by Reclamation staff for this NREL report). 
2017b. "Bureau of Reclamation Renewable Energy Update - Fiscal Year 2017, Q4 Report.” (October 2017). https://www.usbr.gov/power/FY_2017_Q4_Renewable_Update.pdf.

2018a. "Bureau of Reclamation: Hydropower Program - Lease of Power Privilege." https://www.usbr.gov/power/LOPP/index.html. (Accessed February 21, 2018).

2018b. "Bureau of Reclamation Projects \& Facilities - Uncompahgre Project." https://www.usbr.gov/projects/index.php?id=412. (Accessed March 15, 2018).

2018c. Bureau of Reclamation Environmental Compliance NEPA Specialist Interview (February 8, 2018).

2018d. Bureau of Reclamation Electrical Engineer Telephone Interview (February 8, 2018).

2018e. "Bureau of Reclamation Projects \& Facilities - Colorado-Big Thompson Project." https://www.usbr.gov/projects/index.php?id=432. (Accessed March 19, 2018).

2018f. "Bureau of Reclamation - Hydropower Program Webpage.” https://www.usbr.gov/power/who/who.html. (Accessed March 23, 2018).

CEQ (U.S. Council of Environmental Quality). 1981. Memorandum to Agencies: Forty Most Asked Questions Concerning CEQ's National Environmental Policy Act Regulations. 46 Fed. Reg. 18026 (March 23, 1981). https://www.energy.gov/sites/prod/files/G-CEQ-40Questions.pdf.

DMEA (Delta-Montrose Electric Association). 2018a. Telephone interview Delta-Montrose Electric Association project manager (February 7, 2018).

18, 2018).

2018b. “Delta-Montrose Electric Association.” http://www.dmea.com/. (Accessed March

2018c. "Delta-Montrose Electric Association - South Canal Project."

http://www.dmea.com/content/south-canal-project. (Accessed Mar. 20, 2018).

DOE (U.S. Department of Energy). 2010. Memorandum of Understanding Among the Department of Energy, the Department of the Interior, and the Department of the Army. (March 24, 2010). https://openei.org/w/images/9/98/Signedmou.pdf.

2015. Memorandum of Understanding Among the Department of Energy, the Department of the Interior, and the Department of the Army - Five Year Extension. (March 24, 2015). https://www.energy.gov/sites/prod/files/2015/02/f19/Memorandum\%20of\%20Understanding\%2 0for\%20Hydropower\%20March\%202010.pdf.

2016. Hydropower Vision Study. Washington, D.C.

https://www.energy.gov/sites/prod/files/2018/02/f49/Hydropower-Vision-021518.pdf.

FERC (Federal Energy Regulatory Commission). 1992. Memorandum of Understanding Between the Federal Energy Regulatory Commission, and the Department of Interior, Bureau of Reclamation for Establishment of Processes for Early Resolution of Issues Related to the Timely 
Development of Non-Federal Hydroelectric Power at Bureau of Reclamation Facilities. 58 Fed. Reg. 3269 (November 6, 1992). https://www.ferc.gov/legal/mou/mou-6.pdf.

Hadjerioua, B., Wei, Y., Kao, S., 2012. An Assessment of Energy Potential at Non-Powered Dams in the United States. DE-AC05-00R227725, Washington, D.C.: Oak Ridge National Laboratory. https://www1.eere.energy.gov/water/pdfs/npd_report.pdf.

Martinez, R., M. Johnson, P. O’Connor. 2017. “U.S. Hydropower Market Report 2017 Update (April).” Oak Ridge National Laboratory, prepared for the U.S. Department of Energy Water Power Technologies Office. https://www.energy.gov/sites/prod/files/2017/04/f34/USHydropower-Market-Report-2017-Update_20170403.pdf.

Mountain Parks Electric, Inc. 2018a. “MPE’s - Renewable Energy Portfolio.” http://www.mpei.com/content/mpes-renewable-energy-portfolio. (Accessed March 18, 2018).

2018b. “Mountain Parks Electric, Inc.” http://www.mpei.com/. (Accessed March 18, 2018).

NWCD (Northern Water Conservancy District). 2018a. Telephone interview with Northern Water Conservancy District project manager (March 1, 2018).

2018b. "Northern Water - About Us."

http://www.northernwater.org/AboutUs/AboutUs.aspx. (Accessed March 18, 2018).

2018c. Northern Water - Granby Hydropower Plant Brochure.

http://www.northernwater.org/docs/Brochures/Granby_Hydro.pdf. (Accessed March 20, 2018).

Sale, M., Bishop, N., Reiser, S. et al. 2014. Opportunities for Energy Development in Water Conduits: A Report Prepared in Response to Section 7 of the Hydropower Regulatory Efficiency Act of 2013. ORNL/TM-2014/22. Oak Ridge, TN: Oak Ridge National Laboratory.

\section{Federal and State Acts, Statutes, and Bills}

Bureau of Reclamation Small Conduit Hydropower Development and Rural Jobs Act, PL 11324, 127 Stat. 498 (August 9, 2013). https://www.usbr.gov/power/legislation/PLAW113publ24.pdf.

Carl Levin and Howard P. "Buck” McKeon National Defense Authorization Act for Fiscal Year 2015, PL 113-291, 128 Stat. 3292 (December 19, 2014) (authorizes the Secretary of the Interior to lease power privileges at projects constructed pursuant to the Water Conservation and Utilization Act of 1939). https://www.congress.gov/113/plaws/publ291/PLAW-113publ291.pdf.

Department of Interior Appropriations Act of 1938, PL 75-249, 50 Stat. 564, 595 (August 9, 1937).

Endangered Species Act of 1973, PL 93-205, 87 Stat. 884 (16 U.S.C. §§ 1531 - 1544 (December 28, 1973).

National Environmental Policy Act of 1969, PL 91-190, 89 Stat. 852 (42 U.S.C. §§ 4321-4347 (January 1, 1970). 
National Historic Preservation Act of 1966, PL 102-575, 80 Stat. 915 (16 U.S.C. §§ 470 et seq. (October 15, 1966).

Reclamation Act of 1902, PL 75-161, 32 Stat. 388 (43 U.S.C. §§ 391 - 403 (June 17, 1902).

Reclamation Project Act of 1939, PL 75-260, 53 Stat. 1187 (43 U.S.C. §§ 485 - 485k) (August 4, 1939). https://www.usbr.gov/power/legislation/recproja.pdf.

Water Conservation and Utilization Act of 1939, PL 398-76, 53 Stat. 1418 (August 11, 1939). https://www.usbr.gov/power/legislation/WCUA.pdf.

CoLO. REv. STAT. §§ 40-2-101 - 129 (2004), Renewables Energy Standard.

Federal Regulations

40 C.F.R. $\S \S 1508.1$ - 28 (1970), Council on Environmental Quality Rules and Regulations.

43 C.F.R. $\S \S 46.10$ - 46.450 (2008), Department of Interior Rules Implementing the National Environmental Policy Act of 1969. 


\section{Appendix A. Lease of Power Privilege Projects for Timeline Analysis}

\begin{tabular}{|c|c|c|}
\hline Name of Project & Project Initiation Date & Project Online Date \\
\hline Jordanelle Dam (13 MW) & 07/02/1999 & 07/01/2008 \\
\hline Carter Lake Outlet (2.6 MW) & 05/07/2009 & 05/18/2012 \\
\hline South Canal Drop 1 (4 MW) & 08/26/2009 & 06/03/2013 \\
\hline South Canal Drop 3 (3.5 MW) & 08/26/2009 & 08/01/2013 \\
\hline Ridgway Dam (7 MW) & 06/02/2010 & 04/03/2014 \\
\hline Klamath Canal Drop C (900 kW) & 02/08/2011 & 05/03/2012 \\
\hline Granby Dam (1.2 MW) & 04/20/2011 & 05/19/2016 \\
\hline Pueblo Dam (7 MW) & 04/20/2011 & In development \\
\hline Shavano Falls Drop 6 (2.8 MW) & 08/21/2013 & 05/01/2015 \\
\hline South Canal Drop 4 (4.8 MW) & 08/21/2013 & 06/24/2015 \\
\hline A-C3 Panicker Drop (125 kW) & $01 / 14 / 2014$ & In development \\
\hline V-C2 Lewis Wasteway (250 kW) & $01 / 14 / 2014$ & In development \\
\hline South Canal Drop 2 (987 kW) & $05 / 27 / 2014$ & In development \\
\hline South Canal Drop 5 (2.4 MW) & 03/03/2015 & 08/12/2016 \\
\hline
\end{tabular}

